\title{
A Novel Fungal Lipase With Methanol Tolerance and Preference for Macaw Palm Oil
}

\author{
Letícia L. Rade ${ }^{1}$, Melque N. P. da Silva ${ }^{1}$, Plínio S. Vieira', Natalia Milan ${ }^{1,2}$, \\ Claudia M. de Souza ${ }^{1}$, Ricardo R. de Melo', Bruno C. Klein ${ }^{1}$, Antonio Bonomi', \\ Heizir F. de Castro ${ }^{2}$, Mário T. Murakami' and Leticia M. Zanphorlin ${ }^{1 *}$ \\ ' Brazilian Biorenewables National Laboratory, Brazilian Center for Research in Energy and Materials, Campinas, Brazil, \\ ${ }^{2}$ Department of Chemical Engineering, Engineering School of Lorena, University of São Paulo, Lorena, Brazil
}

\section{OPEN ACCESS}

Edited by:

Zhi-Qiang Liu,

Zhejiang University of Technology,

China

Reviewed by:

Dongming Lan,

South China University of Technology,

China

Quanshun Li,

Jilin University, China

Shamsher S. Kanwar,

Himachal Pradesh University, India

*Correspondence:

Leticia M. Zanphorlin

leticia.zanphorlin@/nbr.cnpem.br

Specialty section:

This article was submitted to

Industrial Biotechnology,

a section of the journa

Frontiers in Bioengineering and

Biotechnology

Received: 16 October 2019

Accepted: 20 March 2020

Published: 06 May 2020

Citation:

Rade LL, da Silva MNP, Vieira PS, Milan N, de Souza CM, de Melo RR, Klein BC, Bonomi A, de Castro HF,

Murakami MT and Zanphorlin LM (2020) A Novel Fungal Lipase With Methanol Tolerance and Preference for Macaw Palm Oil.

Front. Bioeng. Biotechnol. 8:304. doi: 10.3389/fbioe.2020.00304
Macaw palm is a highly oil-producing plant, which presents high contents of free fatty acids, being a promising feedstock for biofuel production. The current chemical routes are costly and complex, involving highly harsh industrial conditions. Enzymatic processing is a potential alternative; however, it is hampered by the scarce knowledge on biocatalysts adapted to this acidic feedstock. This work describes a novel lipase isolated from the thermophilic fungus Rasamsonia emersonii (ReLip), which tolerates extreme conditions such as the presence of methanol, high temperatures, and acidic medium. Among the tested feedstocks, the enzyme showed the highest preference for macaw palm oil, producing a hydrolyzate with a final free fatty acid content of $92 \%$. Crystallographic studies revealed a closed conformation of the helical amphipathic lid that typically undergoes conformational changes in a mechanism of interfacial activation. Such conformation of the lid is stabilized by a salt bridge, not observed in other structurally characterized homologs, which is likely involved in the tolerance to organic solvents. Moreover, the lack of conservation of the aromatic cluster IxxWxxxxxF in the lid of ReLip with the natural mutation of the phenylalanine by an alanine might be correlated with the preference of short acyl chains, although preserving catalytic activity on insoluble substrates. In addition, the presence of five acidic amino acids in the lid of ReLip, a rare property reported in other lipases, may have contributed to its ability to tolerate and be effective in acidic environments. Therefore, our work describes a new fungal biocatalyst capable of efficiently hydrolyzing macaw oil, an attractive feedstock for the production of "drop-in" biofuels, with high desirable feature for industrial conditions such as thermal and methanol tolerance, and optimum acidic $\mathrm{pH}$. Moreover, the crystallographic structure was elucidated, providing a structural basis for the enzyme substrate preference and tolerance to organic solvents.

Keywords: biohydrocarbons, "drop-in" biofuels, mechanistic enzyme, Acrocomia aculeate, fungal lipase, macaw oil

\section{INTRODUCTION}

The increasing demand for energy that complies with the current restrictions on emissions of polluting gases is promoting the development and production of alternative fuels from sustainable and renewable sources (Yan et al., 2015; Wang et al., 2018). The biohydrocarbons, in particular, medium- and long-chain fatty alkanes and alkenes, represent very promising alternatives for 
replacing the fossil fuels used in the transportation sector, once they have similar chemical composition and physical characteristics to those of conventional fuels derived from petroleum (Xu et al., 2017). Therefore, biohydrocarbons can share the infrastructure for storage and transportation already used for the distribution of gasoline, diesel, and jet fuel (Yan et al., 2015; Sousa et al., 2018) and can be combined at any proportion with those fuels without any modification in the engines and other mechanical components of the vehicles (Sousa et al., 2018).

Macaw palm (Acrocomia aculeate) is a native species distributed in the tropical and subtropical Americas, and it occurs naturally from southern Mexico to northern Argentina (Ciconini et al., 2013; Pires et al., 2013; Silva et al., 2014; da Conceição et al., 2017). It is predicted that a commercial plantation under appropriate agronomic conditions can produce from 16,000 to $25,000 \mathrm{~kg}$ of fruit per hectare (Pires et al., 2013). Its fruits are oil rich, accumulating up to $70 \%$ of oil (dry weight) and yielding approximately 6,200 $\mathrm{kg}$ of oil per hectare (Pires et al., 2013; Silva et al., 2014). The macaw palm has interesting agronomic and ecological features because it can occupy degraded areas or agroforestry systems given that it has high plasticity to grow in different ecosystems (Moura et al., 2009; Pires et al., 2013), avoiding conflict with areas used for food production. Macaw pulp oil presents a high content of free fatty acids (FFA) and, thus, elevated acidity (Lopes et al., 2013), with oleic acid (C18:1) being the predominant fatty acid (Bora and Rocha, 2004). Thus, it can generate a high-quality biofuel, with high amounts of monounsaturated compounds (Aguieiras et al., 2014).

Currently, the chemical hydrotreatment of acyl glycerides, fatty acids, or esters is the route commonly applied to obtain biohydrocarbons (Gosselink et al., 2013; Kim et al., 2014; Chen et al., 2016; Karatzos et al., 2017; Pattanaik and Misra, 2017; Khan et al., 2019; Scaldaferri and Pasa, 2019). However, this process requires high-cost metallic catalysts, large amounts of hydrogen, elevated temperatures and highpressure conditions, which makes it not economically viable, technologically complex, and environmentally unfavorable (Zhang et al., 2011; Yan et al., 2015; Sousa et al., 2018; Li et al., 2019). Alternatively, enzymatic routes for biohydrocarbon production have been investigated since they can act at mild industrial conditions and present high selectivity, which precludes undesirable side reactions, besides providing pure products with high yields (Beller et al., 2010; Schirmer et al., 2010; Wang and Lu, 2013; Herman and Zhang, 2016; Scrutton, 2017; Wise et al., 2017; Zargar et al., 2017; Knoot and Pakrasi, 2019).

Lipases (triacylglycerol acylhydrolases, E.C. 3.1.1.3) are watersoluble enzymes (Reis et al., 2009) that can catalyze oil hydrolysis, esterification, and transesterification (Goswami et al., 2013). Most of them are interfacial enzymes, which means that, at the oilwater interface, they undergo structural changes that involve a movement of a short helical segment (lid) that covers the active site. Thus, during the activation process, the lid changes its conformation, exposing the catalytic triad and increasing the aliphatic surface surrounding the active site, required for substrate binding (Derewenda et al., 1992; Maruyama et al., 2000; Gruber and Pleiss, 2012). In addition, due to their transesterification activity, during the last decade, lipases have been extensively studied as a promising industrial biocatalyst for biodiesel production (Bajaj et al., 2010; Hwang et al., 2014; Norjannah et al., 2016; Amini et al., 2017). It has recently been reported that few vegetable lipases, especially those from castor bean seeds, are more effective on the hydrolysis of macaw oil because they usually act at acidic pHs compared to fungal lipases that perform under more basic conditions (Ory et al., 1962; Muto and Beevers, 1974; Avelar et al., 2013; Bressani et al., 2015).

Therefore, considering the interest to make macaw palm an alternative platform to produce renewable biofuel and other bioproducts, and the very limited knowledge of biocatalysts available that can convert this specific acidic oil, the aim of this work was to develop a fungal lipase that could be compatible and efficient for this feedstock. Rasamsonia emersonii is an important microbial platform for cellulose degradation since its genome possesses many effective glycoside hydrolases (Gudmundsson et al., 2016; Martínez et al., 2016); nevertheless, it remains underexplored regarding enzymes active on triglycerides. For the first time, we have cloned and heterologously expressed the lipase from Rasamsonia emersonii (ReLip). The functional analysis revealed that ReLip has an optimum acidic $\mathrm{pH}$ profile and was active on a wide range of substrates from short to long carbon length chains. The enzyme was remarkably active on macaw oil, being able to produce a total of $92 \%$ FFA content. Furthermore, ReLip is highly thermo-tolerant under extreme conditions such as in the presence of methanol. Crystallographic analysis revealed the closed conformation of this lipase indicating structural properties driving substrate selectivity and tolerance to organic solvents. In this sense, this work, besides providing a novel effective biocatalyst suitable for typical harsh industrial conditions, reveals new molecular aspects associated with substrate preference and tolerance to extreme conditions.

\section{MATERIALS AND METHODS}

The lipase gene from Rasamsonia emersonii cloned into the pET28a(+) vector with a histidine-tag at the N-terminus was purchased from Genscript (Piscataway, NJ, United States) (GenBank accession number: 915129218). Gum Arabic and ethanol (minimum 99.5\%) were purchased from Synth and acetonitrile (minimum 99.9\%) from Tedia. Commercial soybean (Liza), canola (Liza), olive (Gallo), sunflower (Liza), corn (Liza), and coconut oils were obtained at local markets. Palm and macaw oils were kindly supplied by Agropalma and Dr. Carlos Colombo [Agronomic Institute of Campinas (IAC), respectively]. FFA composition and percentage of FFA (acidity) of the vegetable oils used in this work are described in Supplementary Table S1. The FFA content was measured according to AOCS standard number Ca 5a-40 (Walker, 1990). The fatty acid composition of each oil was determined using a Pegasus HT (Leco) connected to a gas chromatographer (7890A, Agilent), according AOCS standard Ce 1-62 method (AOCS, 2005). 


\section{Protein Expression and Purification}

The plasmid ReLip1-pET28a was produced in E. coli BL21(DE3)pLysS strain with pRARE2 plasmid. The cells were cultured in Luria-Bertani (LB) agar containing $25 \mu \mathrm{g} / \mathrm{ml}$ of kanamycin and chloramphenicol. For growth, one colony was picked and cultured in $5 \mathrm{ml}$ of LB broth containing $25 \mu \mathrm{g} / \mathrm{ml}$ of kanamycin and chloramphenicol, with overnight shaking at $37^{\circ} \mathrm{C}$ and $250 \mathrm{rpm}$. After this period, the material was diluted 100-fold with fresh selective terrific broth (TB) and incubated at $37^{\circ} \mathrm{C}$ until an optical density $\left(\mathrm{OD}_{600 \mathrm{~nm}}\right)$ of 1.2. Thus, the protein expression was subsequently induced by $0.5 \mathrm{mM}$ isopropyl $\beta$-D-1-thiogalactopyroanoside (IPTG) and cultivated for $16 \mathrm{~h}$ at $20^{\circ} \mathrm{C}$ and $250 \mathrm{rpm}$. The cells were collected by centrifugation at $8,000 \times g$ for $20 \mathrm{~min}$ at $4^{\circ} \mathrm{C}$ and resuspended in $20 \mathrm{ml}$ of lysis buffer $(50 \mathrm{mM}$ phosphate $\mathrm{pH} 7.4$, $300 \mathrm{mM} \mathrm{NaCl}, 30 \mathrm{mM}$ imidazole, $1 \mathrm{mM}$ phenylmethylsulfonyl fluoride (PMSF), and $0.5 \mathrm{mg} \mathrm{ml}-1$ of lysozyme). The cells were, then, lysed by sonication, and the soluble protein was extracted by centrifugation at $12,000 \times \mathrm{g}$ for $30 \mathrm{~min}$ at $4^{\circ} \mathrm{C}$. Thereafter, the enzyme was purified from the supernatant by two chromatographic steps: (i) metal-affinity chromatography, using a non-linear imidazole gradient $(20-500 \mathrm{mM})$ in a $5-\mathrm{ml}$ HisTrap HP column (GE Healthcare), previously equilibrated with $50 \mathrm{mM}$ phosphate buffer, $\mathrm{pH} 7.4,20 \mathrm{mM}$ imidazole, and $300 \mathrm{mM} \mathrm{NaCl}$ and (ii) size-exclusion chromatography using a Superdex 200 HiLoad 16/60 column (GE Healthcare), previously equilibrated with $50 \mathrm{mM}$ phosphate buffer, $\mathrm{pH}$ 7.4 and $150 \mathrm{mM} \mathrm{NaCl}$ coupled to an AKTÄ Purifier FPLC system (GE Healthcare Life Sciences). All steps of heterologous expression and enzyme purification were analyzed by sodium dodecyl sulfate-polyacrylamide gel ( $12 \%$ polyacrylamide) electrophoresis (SDS-PAGE). The protein concentration was spectroscopically determined using the molar extinction coefficient calculated from the amino acid composition ${ }^{1}$, which is $38,765 \mathrm{M}^{-1} \mathrm{~cm}^{-1}$.

\section{Biochemical Characterization on Synthetic Substrates}

The substrate specificity of ReLip was evaluated at the following substrates: $p$ NP palmitate (C16:0), $p$ NP myristate (C14:0), $p$ NP dodecanoate (C12:0), $p$ NP decanoate (C10:0), $p$ NP octanoate (C8:0), $p \mathrm{NP}$ valerate (C5:0), $p \mathrm{NP}$ butyrate (C4:0), $p \mathrm{NP}$ acetate (C2:0), and $p$ NP format (C1:0). All $p$ NP solutions $(20 \mathrm{mM})$ were prepared in acetonitrile/isopropanol $(1 / 4 v / v)$ and $0.3 \%(v / v)$ Triton X-100. The experiments were carried out in 96-well plates, with a reaction volume of $100 \mu \mathrm{l}$ composed of $0.5 \mathrm{mg}$ of purified enzyme, $40 \mathrm{mM}$ citrate buffer ( $\mathrm{pH} 3.5)$, and $5.0 \mathrm{mM}$ pNPs. The system was incubated for $20 \mathrm{~min}$ at $65^{\circ} \mathrm{C}$ in a Veriti Thermal Cycler (Applied Biosystems, United States), and the reactions were ended by adding $100 \mu \mathrm{l}$ of pure acetonitrile. The final absorbances were measured at $348 \mathrm{~nm}$, which is the isosbestic point of $p$-nitrophenol and p-nitrophenoxide (Rhee et al., 2005; Glogauer et al., 2011), using an Infinite ${ }^{\circledR} 200$ PRO microplate reader (TECAN Group Ltd., Switzerland). All reactions were

\footnotetext{
${ }^{1}$ http://web.expasy.org/protparam/
}

performed in quadruplicates. Control points were made using water instead of enzyme. The measurements were expressed as relative activity (\%) considering the maximum catalytic activity observed for the biological unit of the enzyme.

The optimum temperature and $\mathrm{pH}$ of the enzyme was determined spectrophotometrically following the hydrolysis of $p$-nitrophenylbutyrate ( $p$ NPB; C4:0; Sigma-Aldrich Co., St. Louis, United States) at $348 \mathrm{~nm}$. The reactions were performed as described above. The thermostability and the optimal temperature of the ReLip were evaluated in a temperature range of $35^{\circ} \mathrm{C}$ to $75^{\circ} \mathrm{C}$, at $\mathrm{pH} 4.0$. The optimum $\mathrm{pH}$ for ReLip activity was determined in the $\mathrm{pH}$ range of 2.0 to 6.0 at $65^{\circ} \mathrm{C}$, using the following buffers: HCl-glycine $(\mathrm{pH} 2.0$ and 2.5) and citrate $(\mathrm{pH} 3.0,3.5,4.0,4.5,5.0,5.5$, and 6.0), at a final concentration of $40 \mathrm{mM}$.

The additives tested were cations $\left(\mathrm{NaCl}, \mathrm{CaCl}_{2}, \mathrm{MgCl}_{2}, \mathrm{KCl}\right.$, $\mathrm{BaCl}_{2}, \mathrm{MnCl}_{2}, \mathrm{NiCl}_{2}, \mathrm{CoCl}_{2}, \mathrm{CuCl}_{2}$, and $\mathrm{FeCl}_{3}$ at $10 \mathrm{mM}$ ), anions $\left(\mathrm{H}_{2} \mathrm{SO}_{4}, \mathrm{CH}_{3} \mathrm{COOH}, \mathrm{H}_{3} \mathrm{PO}_{4}\right.$, and $\mathrm{HNO}_{3}$ at $\left.10 \mathrm{mM}\right)$, detergents (Tween 20, Tween 80 and sodium docecyl sulfate, SDS (1\%) and Triton X-100 from 0.1 to $10 \%$ ), chelating agent (ethylenediamine tetraacetic acid, EDTA at $10 \mathrm{mM}$ ), modifying agents (diethyl pyrocarbonate, DEPC at $1 \mathrm{mM}$ ), and gum arabic, from $0.1 \%$ to $10 \%(\mathrm{v} / \mathrm{v})$.

Each additive was investigated in individual $100-\mu 1$ reactions containing $5 \mathrm{mM}$ substrate $p \mathrm{NPB}, 100 \mathrm{mM}$ citrate-phosphate buffer $(\mathrm{pH} 3.5)$, and $0.5 \mathrm{~g} / \mathrm{L}$ of enzyme. The samples were incubated at $65^{\circ} \mathrm{C}$ for $20 \mathrm{~min}$, and then, $100 \mu \mathrm{l}$ of pure acetonitrile was added to stop the reaction. The activity was determined by absorbance measurement at $348 \mathrm{~nm}$ and compared to the control, which was incubated without any compound. The activity measured without additives was defined as $100 \%$. Then, the evaluation was expressed as relative activity (\%).

\section{Circular Dichroism (CD) Analysis}

Circular dichroism (CD) measurements were carried out in a Jasco J-815 spectropolarimeter (Jasco, United States), using a Peltier-type temperature control system for temperature maintenance inside the cell. For the analysis of the secondary structure, the purified and homogeneous enzyme was diluted to multiple buffers in different conditions. Data were collected from 260 to $190 \mathrm{~nm}$ at $20^{\circ} \mathrm{C}$, using a $\mathrm{N}_{2}$ flow rate of $10 \mathrm{ml} / \mathrm{min}$, quartz cuvette with $0.1 \mathrm{~cm}$ of path length, scan speed of $50 \mathrm{~nm} / \mathrm{min}$, response time of $1.0 \mathrm{~s}$, spectral bandwidth of $1.0 \mathrm{~nm}$ and spectral resolution of $0.1 \mathrm{~nm}$. The final CD spectrum obtained was an average of 20 accumulations.

The CD spectroscopy was also applied to determine the protein stability at denaturing conditions, by measuring thermalinduced unfolding and melting temperature. For this purpose, the sample was heated from $20^{\circ} \mathrm{C}$ to $100^{\circ} \mathrm{C}$ at a rate of $1.0^{\circ} \mathrm{C} / \mathrm{min}$. The reversibility of the temperature effect was evaluated by cooling the denatured sample from $100^{\circ} \mathrm{C}$ to $20^{\circ} \mathrm{C}$, using the same parameters described above. The values obtained in $\mathrm{CD}$ measurements (mDeg) were normalized to residual molar ellipticity (MRE), and the temperature at the midpoint transition $\left(T_{m}\right)$ was obtained by fitting the $\mathrm{CD}$ data to a sigmoidal 
Boltzmann function. Data were treated using the software Origin 8.1 (OriginLAB Corporation).

\section{Determination of Hydrolytic Activity Using Triacylglycerol Substrates}

The hydrolytic activity of the ReLip was determined on the hydrolysis of emulsified vegetable oils (Soares et al., 1999), aiming at verifying the optimum temperature and $\mathrm{pH}$ using triacylglycerol substrates and assessing the substrate specificity of the lipase. For the substrate specificity tests, vegetable oils such as soybean, canola, olive, sunflower, palm, macaw, corn, and coconut were used. The substrates were prepared by the emulsion of $7.5 \mathrm{~g}$ of vegetable oil, $67.5 \mathrm{~g}$ of water, $6.57 \mathrm{~g}$ of gum arabic (10\% of water weight), and $60 \mathrm{ml}$ of citrate buffer ( $\mathrm{pH} 4.0,50 \mathrm{mM}$ ), resulting in a final oil concentration of $5 \%$. For the experiments, protein (at a final concentration of $2 \mathrm{~g} / \mathrm{L}$ ) and substrate were added (final reaction volume of $10 \mathrm{ml}$ ) into $125-\mathrm{ml}$ Erlenmeyer flasks and incubated at $60^{\circ} \mathrm{C}$ and $200 \mathrm{rpm}$ for $5 \mathrm{~min}$ in an incubator shaker (Innova 44, New Brunswick Scientific, United States). After the incubation period, the reactions were ended by the addition of $10 \mathrm{ml}$ of ethanol P.A. (Synth).

For the analysis of optimum temperature and $\mathrm{pH}$ and the design of experiments, the hydrolysis reactions were performed using pulp macaw oil. The emulsion was prepared as described above. Thus, substrate and protein, at pre-defined proportions and final volume of $10 \mathrm{ml}$, were added into 125-ml Erlenmeyer flasks and incubated at $35^{\circ} \mathrm{C}$ and $200 \mathrm{rpm}$. After the desired time of reaction, the experiments were stopped by the addition of $10 \mathrm{ml}$ of acetonitrile. The fatty acids produced in the hydrolysis were titrated with $\mathrm{KOH}$ solution, $0.2 \mathrm{~mol} \mathrm{~L}^{-1}$, using phenolphthalein as indicator. The hydrolysis degree was calculated according to Eq. (1) (Rooney and Weatherley, 2001):

Hydrolysis degree $(\%)=\left(\frac{V \times 10^{-3} \times M_{K O H} \times M M_{F F A}}{w \times f}\right) \times 100$

where $V$ is the volume of potassium hydroxide solution required in the titration process $(\mathrm{ml}), M_{\mathrm{KOH}}$ is the $\mathrm{KOH}$ solution concentration $(\mathrm{mol} / \mathrm{L}), M M_{F F A}$ is the average molecular mass of fatty acids of the macaw oil $(276.01 \mathrm{~g} / \mathrm{mol}), \mathrm{w}$ is the weight of the sample titrated $(\mathrm{g})$, and $\mathrm{f}$ is the fraction of oil in the begging of the reaction.

\section{Design of Experiments and Optimization}

The experiments were performed at $35^{\circ} \mathrm{C}$ and $\mathrm{pH}$ 4.0. A matrix of 12 experiments were performed in duplicate, using alpha for orthogonality $(\alpha)$ of 1.21 and four replications at the center point. The independent parameters were defined as follows: catalyst concentration $(C)$ and time of reaction $(t)$. Supplementary Table $\mathbf{2} 2$ shows the variables used in the central composite design (CCD), with their five coded and uncoded levels. The response variable was defined as the hydrolysis degree. The hydrolysis degree obtained were fitted in a quadratic model using regression analysis, and for selecting the significant terms of the model, parameters with values of $p<0.05$ were considered statistically significant. The range of each parameter was selected according to preliminary tests. For the optimization process, canonical analysis technique was employed (Box and Tiao, 1977). Thus, aiming at validating the optimization, the enzymatic hydrolysis was performed under the optimal experimental conditions suggested by the analysis. In this work, the CCD and RSM were developed by Statistica software version 7.0 (Statsoft, United States), and the canonical analysis was implemented using the software Maple 17.

\section{Dynamic Light Scattering (DLS)}

Dynamic light scattering (DLS) technique was used to determine the hydrodynamic behavior of ReLip in buffer purification at different concentrations $(1-10 \mathrm{mg} / \mathrm{ml})$. The experiments were carried out at room temperature using a Malvern Zetasizer Nano ZS90 (Malvern Instruments, Worcestershire, United Kingdom) with a 633-nm laser, in a quartz cell with a scattering angle of $90^{\circ}$. The diffusion coefficient (DT) was determined from the analysis of measured time-dependent fluctuations in the scattering intensity and used to calculate the hydrodynamic radius $(\mathrm{Rh})$ of the protein according to the Stokes-Einstein equation.

\section{Small-Angle X-Ray Scattering (SAXS)}

Small-angle $\mathrm{X}$-ray scattering measurements were acquired using a monochromatic X-ray beam $(\lambda=1.488 \AA)$ from the D01ASAXS2 beamline at the Brazilian Synchrotron Light Laboratory (LNLS, Brazil). ReLip (2-4 mg/ml) samples were prepared in buffer purification. Prior to conducting the SAXS experiments, all samples were centrifuged for $15 \mathrm{~min}$ at $20,000 \times g$ and $4^{\circ} \mathrm{C}$ to remove any potential residual aggregates. The sample-todetector distance was set as $1,000 \mathrm{~mm}$, resulting in a scattering vector $(q)$ range of $0.02 \AA^{-1}<q<0.50 \AA^{-1}$, where the $q$-vector magnitude is defined as $q=4 \pi \sin \theta / \lambda$ in which $2 \theta$ is the scattering angle. Samples were analyzed at $20^{\circ} \mathrm{C}$ and placed in 1-mm-path-length mica cells, and the scattering profiles were recorded in 10 successive frames (30 s each) to monitor radiation damage. The buffer contribution in each SAXS profile was subtracted taking into account the attenuation and integrated in the sample using the FIT2D software (Hammersley, 2016). Sample mono dispersity was checked by means of the Guinier's law, and all studied systems presented here were found to be monodisperse, and no aggregation took place over the SAXS curves (data not shown). The Gnom program (Svergun et al., 1988) was also used to generate the pair distance distribution function $[p(r)]$ and the protein maximum dimension $\left(D_{\max }\right)$ from scattering profiles. Employing the $p(r)$ function, the DAMMIN software (Svergun, 1999) was applied to obtain $a b$ initio models for ReLip (dummy atom model) by a simulated annealing optimization routine that yields a best fit to the experimental scattering data. Shapes were reconstructed by averaging a minimum of 10 different $a b$ initio models using the DAMAVER package (Volkov and Svergun, 1995). The experimentally derived low-resolution envelopes were superimposed on structures obtained by molecular modeling using the SUPCOMB software (Kozin and Svergun, 2001). 


\section{Crystallization, Data Collection, and Processing}

Multiple amino acid sequence alignment of fungal lipase sequences was performed using Clustal Omega and ESPript 3.0. The following lipases were aligned: 1DT3: Thermomyces lanuginosus lipase, $62.08 \%$ identity; 1TIA: Penicillium camemberti lipase, $49.26 \%$ identity; 5CH8: Penicillium cyclopium lipase, 48.90\% identity; 5XK2: Aspergillus oryzae lipase, $42.35 \%$ identity; 3NGM: Fusarium graminearum lipase, $45.76 \%$ identity; 4L3W: Rhizopus microsporus var. chinensis lipase, 29.92\% identity; 1LGY: Rhizopus Niveus lipase, 31.65\% identity; 5TGL: Rhizomucor miehei lipase, 34.53\% identity; 2HL6: Aspergillus niger feruloyl esterase, 30.85\% identity (Supplementary Figure S1). Protein sample at a concentration of $16.5 \mathrm{mg} \mathrm{ml}^{-1}$ in $50 \mathrm{mM}$ sodium phosphate, $\mathrm{pH} 7.4$, and $150 \mathrm{mM} \mathrm{NaCl}$ buffer was used in the crystallization experiments. The sample was under sitting-drops prepared at $18^{\circ} \mathrm{C}$ using a Cartesian HoneyBee 963 system (Genomic Solutions). Conditions (544) were tested, based on commercially available crystallization kits from Hamptom Research (SaltRx, Crystal Screens I and II), Emerald BioSystems (Precipitant Synergy and Wizard I and II), and Qiagen/Nextal (PACT and JCSG+). The drop, composed of $0.7 \mu \mathrm{l}$ of the protein solution and $0.3 \mu \mathrm{l}$ of the condition, was equilibrated over the reservoir containing $80 \mu \mathrm{l}$ of the respective solution. Crystal optimization was performed using a systematic grid in which PEG 8000 concentration (from $20 \%$ to $8 \%$ ) was varied in function of PEG 400 (from $20 \%$ to $8 \%$ ) in a solution of $100 \mathrm{mmol} / \mathrm{L}$ $\mathrm{MgCl}_{2}$ and $100 \mathrm{mmol} / \mathrm{L}$ Tris buffer $\mathrm{pH}$ 8.5. Two crystals with approximate dimensions of $30 \times 30 \mu \mathrm{m}$ were obtained. The solution consisted of $100 \mathrm{mmol} / \mathrm{L} \mathrm{MgCl}_{2}, 20 \%$ PEG 8000, 20\% PEG 400, $100 \mathrm{mmol} / \mathrm{L}$ Tris buffer $\mathrm{pH}$ 8.5. The crystallization conditions are summarized in Supplementary Table S3.

Diffraction data were collected at the BL12-2 beamline from the Stanford Synchrotron Radiation Lightsource (Menlo Park, CA, United States). Crystals were cooled in liquid nitrogen and kept under a nitrogen gas stream during the collection at $100 \mathrm{~K}$. A total of 1,800 images were collected, and data were indexed, integrated, and scaled using XDS package (Kabsch, 2010). Pointless (Evans, 2006, 2011) and Zanuda (Lebedev and Isupov, 2014) were used to select and validate the chosen space group. Data analysis was performed with Xtriage (Zwart et al., 2005; Adams et al., 2010), and detection of anisotropy was made using the diffraction anisotropy server (Strong et al., 2006). Supplementary Table S4 presents the parameters used in the data processing.

\section{RESULTS AND DISCUSSION}

\section{ReLip Presents an Uncommon Acidic pH-Activity Profile and Its Catalytic Activity Is Not Metal Dependent}

ReLip was overexpressed in the soluble and stable form in E. coli BL21(DE3)plysS yielding $120 \mathrm{mg} / \mathrm{L}$ of TB medium. After steps of purification, fractioned samples were analyzed by SDSPAGE (Supplementary Figure S2). ReLip showed a single band between 31 and $45 \mathrm{kDa}$ after size exclusion chromatography, corresponding to the expected molecular weight of the construct with an N-terminal His-tag $(31.75 \mathrm{kDa})$.

The effects of $\mathrm{pH}$ and temperature on ReLip activity were investigated using $p$ NPB as substrate. Figure $1 \mathrm{~A}$ shows the effect of temperature variation on the enzymatic activity, from $35^{\circ} \mathrm{C}$ to $75^{\circ} \mathrm{C}$ at $\mathrm{pH}$ 4.0. The optimum temperature profile revealed that ReLip possesses a high thermal stability, with a relative activity of $60 \%$ at lower temperatures and a maximum activity around $65^{\circ} \mathrm{C}$ when analyzed using a synthetic substrate. In Figure 1B, it is possible to observe the effect of $\mathrm{pH}$, varying from 2 to 6 . According to the $\mathrm{pH}$ profile, ReLip works better at acidic conditions, with an optimum $\mathrm{pH}$ around 3.5. Based on these results, ReLip shows an interesting feature when compared to most of the industrial lipases from fungi. Usually, lipases, mainly from microbial origin, act in an alkaline spectrum (Papaparaskevas et al., 1992; Soares et al., 1999; Hiol et al., 2000; Saxena et al., 2003; Yu et al., 2007; Utsugi et al., 2009; Belhaj et al., 2011). Only a few lipases, like the lipase from Aspergillus niger, show such acidic profile (Romero et al., 2007).

Knowing that additives can improve the enzymatic activity of lipases (Priyanka et al., 2019), ReLip was tested in the presence of a wide range of additives, such as detergents, chelating and modifying agents, cations, anions, and gum arabic. The results are shown in Table 1. Among the salts tested, only $\mathrm{NaCl}$ increased the relative activity. Considering this result, an investigation using different concentrations of $\mathrm{NaCl}$ was carried out, aiming at better understanding the effect of ionic strength on enzymatic activity. In the presence of $50 \mathrm{mM} \mathrm{NaCl}$, ReLip had its relative activity increased twofold with small increments in the activity up to 0.5 M. Inhibition effects were observed only at concentrations higher than $1 \mathrm{M}$. Calcium was also evaluated in the range from 0.01 to 2 $\mathrm{M}$, since this divalent cation is usually an important cofactor for lipase activity (Shibata et al., 1998; Simons et al., 1999; Choi et al., 2005; Tayyab et al., 2011; Lan et al., 2015). Different from typical lipases, no significant improvement in the activity was observed with calcium, indicating that ReLip is not a metal-dependent enzyme. This was further supported by the fact that the chelating agent, EDTA, did not substantially affect the catalytic activity.

The presence of gum arabic and detergents was also tested (Table 1), once those compounds are typically used in substrate emulsions to stabilize and improve emulsion quality (Glogauer et al., 2011). Regarding gum arabic, its presence did not considerably increase the activity or promote inhibition at any of the concentrations tested, indicating that this gum can be used in the preparation of substrate emulsions for the application of ReLip. Among the detergents, SDS, Tween $80 \%$ and Tween $20 \%$ decreased the activity of the enzyme, especially SDS, with a remaining relative activity of only $11 \%$. However, Triton X-100 showed a great and significant effect as additive for ReLip activity. An increase in the concentration of this additive promoted an activation on the activity, achieving the highest relative activity of $177 \%$ at a concentration of $0.5 \%$. The inhibition process only started at concentrations above $10 \%$, possibly due to a denaturation process (Glogauer et al., 2011). Considering that Tween and Triton X-100 are non-ionic detergents (with low hydrophilic/lipophilic balance value), they probably did not 
A

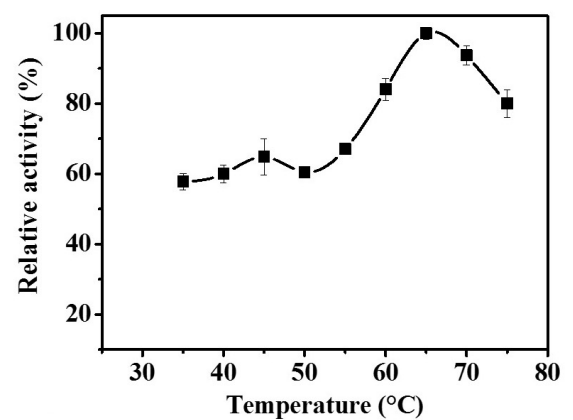

C

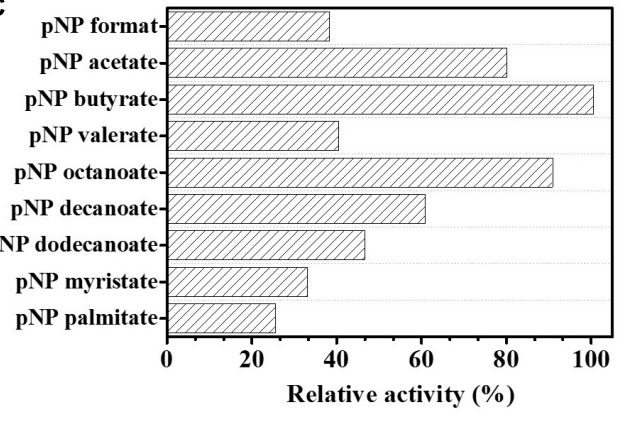

$* 100 \%$ corresponds to $59.34 \mathrm{U} / \mathrm{g}$
B

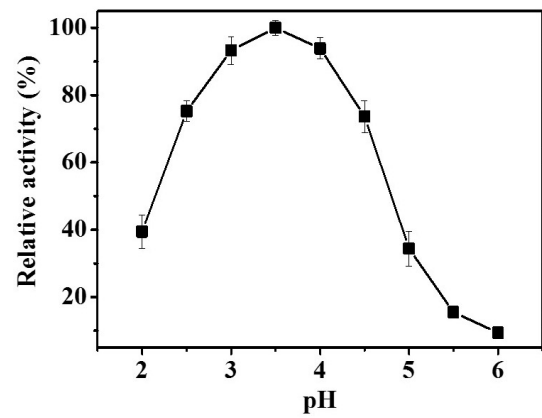

D

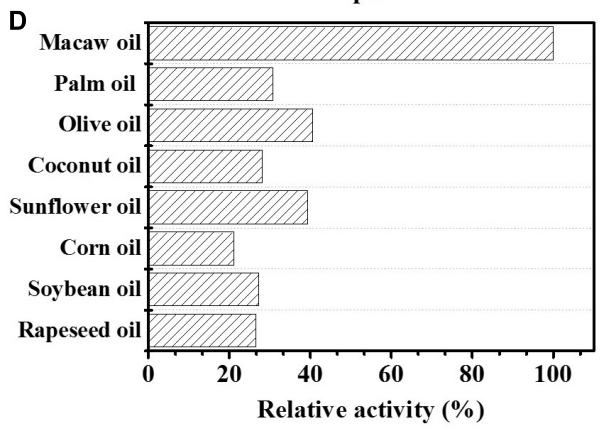

* $100 \%$ corresponds to $2000.36 \mathrm{U} / \mathrm{g}$

FIGURE 1 | Effect of temperature (A) and pH (B) on the activity of the purified lipase from Rasamsonia emersonii (ReLip). The temperature effect was evaluated from $35^{\circ} \mathrm{C}$ to $75^{\circ} \mathrm{C}$, at $\mathrm{pH} 4.0$, while $\mathrm{pH}$ influence was assessed at $65^{\circ} \mathrm{C}$ using different buffers (pH 2.0 to 6.0). (C) ReLip specificity against synthetic substrates (pNPs) with different chain lengths $\left(65^{\circ} \mathrm{C}, \mathrm{pH} 3.5\right.$, incubated for $\left.20 \mathrm{~min}\right) ; 100 \%$ of activity corresponds to $59.34 \mathrm{U} / \mathrm{g}$. (D) Hydrolytic activity of ReLip using different vegetable oils $\left(5 \mathrm{wt} \%, 60^{\circ} \mathrm{C}, \mathrm{pH} 4.0\right.$, incubated for $5 \mathrm{~min}$ ); $100 \%$ of activity corresponds to 2,000.36 U/g. All measurements were conducted in triplicate. The relative activity (\%) was calculated considering the maximum catalytic activity observed for the biological unit of the enzyme, and the specific activity was defined as the number of units per $\mathrm{g}$ of protein.

interact extensively with the surface of proteins. On the other hand, ionic detergents, such as SDS, may have non-specific interactions with the surface of the proteins, facilitating structure denaturation (Priyanka et al., 2019).

\section{ReLip Is a Lipase With Preference for Macaw Oil as Substrate}

In order to identify the specificity of ReLip, the enzymatic activity was evaluated as a function of different chain lengths of $p$-nitrophenyl substrates (Figure 1C). The results showed that ReLip was able to hydrolyze all substrates tested. However, ReLip preferentially hydrolyzed short acyl chains, showing higher activities against $p \mathrm{NP}$ butyrate (C4:0), $p \mathrm{NP}$ octanoate (C8:0), and $p N P$ acetate (C2:0), with relative activities of $100 \%, 90.9 \%$, and $80.1 \%$, respectively. The lowest relative activity was observed against $p$ NP palmitate $(\mathrm{C} 16: 0)$. It is known that one of the main differences between esterase and lipase is the fact that while esterase acts only on soluble substrates with smaller chains, lipases can hydrolyze insoluble substrates with larger chains above 10 carbons. The assays in the presence of $p$ NPs with different sizes revealed that ReLip has the ability to act on both short and long chains and consequently, ReLip can be classified as an enzyme with esterase and lipase activity (Sharma et al., 2001, 2013; Jaeger et al., 2002; Silva et al., 2009). Thus, in order to prove the activity on insoluble substrates and confirm that ReLip is a true lipase, the hydrolytic activity using different emulsified vegetable oils, such as soybean, canola, olive, sunflower, palm, macaw, corn, and coconut, was evaluated (Figure 1D). It is possible to observe that ReLip was active against all oils tested, presenting a sequential preference for macaw oil $(2,000 \mathrm{U} / \mathrm{g})$, followed by olive oil $(811 \mathrm{U} / \mathrm{g})$, and sunflower oil $(788 \mathrm{U} / \mathrm{g})$. These results showed that the hydrolytic activity depends on a wide range of factors and not only on the length of the acyl chain and the amount of unsaturation. Probably, the high amounts of FFA in the macaw oil led to an acidification of the medium that benefited the hydrolytic activity of ReLip.

In view of the preference for hydrolyzing macaw oil, the optimum temperature and $\mathrm{pH}$ profiles using this oil as substrate were also evaluated (Supplementary Figure S3). The enzyme showed a distinct temperature dependence using the macaw oil as substrate compared to the synthetic substrate $(p \mathrm{NPB})$, with an activity plateau in the temperature range from $25^{\circ} \mathrm{C}$ to $50^{\circ} \mathrm{C}$ (Supplementary Figure S3A). Despite that, the enzyme retained up to $73.3 \%$ of its activity after $24 \mathrm{~h}$ of incubation in this temperature range, indicating a high stability under these conditions (Supplementary Figure S3C). Regarding the $\mathrm{pH}$ profile, both synthetic and natural substrates exhibited the optimum pH at 4.0 (Supplementary Figure S3B). Thus, to obtain the kinetic profile of macaw oil hydrolysis, the experiments were set at $35^{\circ} \mathrm{C}$ and $\mathrm{pH} 4.0$. The data revealed a hydrolysis degree of $50 \%$ with $3 \mathrm{~h}$ of reaction, and $63 \%$ was obtained 
TABLE 1 | Effect of additives on ReLip activity.

\begin{tabular}{|c|c|c|c|c|c|}
\hline Additives & Relative activity (\%) & Additives & Relative activity (\%) & Additives & Relative activity (\%) \\
\hline Cation (10 mM) & & Sodium chloride & & Calcium chloride & \\
\hline Control & $100.0 \pm 2.5$ & Control & $100.0 \pm 3.9$ & Control & $100.0 \pm 4.1$ \\
\hline $\mathrm{NaCl}$ & $142.2 \pm 4.5$ & $0.010 \mathrm{M}$ & $155.0 \pm 11.2$ & $0.010 \mathrm{M}$ & $121.5 \pm 2.7$ \\
\hline $\mathrm{CaCl}_{2}$ & $122.8 \pm 4.7$ & $0.050 \mathrm{M}$ & $203.3 \pm 9.2$ & $0.05 \mathrm{M}$ & $92.7 \pm 3.9$ \\
\hline $\mathrm{MgCl}_{2}$ & $107.2 \pm 8.5$ & $0.10 \mathrm{M}$ & $151.5 \pm 3.5$ & $0.10 \mathrm{M}$ & $90.5 \pm 5.6$ \\
\hline $\mathrm{KCl}$ & $101.1 \pm 7.1$ & $0.15 \mathrm{M}$ & $145.3 \pm 6.8$ & $0.15 \mathrm{M}$ & $74.8 \pm 8.1$ \\
\hline $\mathrm{BaCl}_{2}$ & $90.6 \pm 4.5$ & $0.20 \mathrm{M}$ & $122.0 \pm 7.6$ & $0.20 \mathrm{M}$ & $40.3 \pm 4.3$ \\
\hline $\mathrm{MnCl}_{2}$ & $85.7 \pm 5.3$ & $0.50 \mathrm{M}$ & $102.5 \pm 4.9$ & $0.50 \mathrm{M}$ & $39.6 \pm 8.6$ \\
\hline $\mathrm{NiCl}_{2}$ & $77.4 \pm 6.3$ & $1.0 \mathrm{M}$ & $86.1 \pm 8.2$ & $1.0 \mathrm{M}$ & $34.6 \pm 7.7$ \\
\hline $\mathrm{CoCl}_{2}$ & $66.3 \pm 6.8$ & $1.5 \mathrm{M}$ & $50.0 \pm 1.5$ & $1.5 \mathrm{M}$ & $23.6 \pm 3.8$ \\
\hline $\mathrm{CuCl}_{2}$ & $53.5 \pm 4.1$ & $2.0 \mathrm{M}$ & $37.5 \pm 7.1$ & $2.0 \mathrm{M}$ & $23.3 \pm 7.0$ \\
\hline $\mathrm{FeCl}_{3}$ & $29.1 \pm 7.0$ & & & & \\
\hline Anion (10 mM) & & Triton X-100 & & Gum arabic & \\
\hline Control & $100.0 \pm 2.5$ & Control & $100.0 \pm 4.7$ & Control & $100.0 \pm 6.6$ \\
\hline $\mathrm{PO}_{4}^{-}$ & $68.7 \pm 1.6$ & $0.10 \%$ & $116.7 \pm 6.6$ & $0.10 \%$ & $112.0 \pm 3.1$ \\
\hline $\mathrm{SO}_{4}^{-}$ & $105.9 \pm 4.9$ & $0.30 \%$ & $137.5 \pm 11.8$ & $0.30 \%$ & $112.1 \pm 2.8$ \\
\hline $\mathrm{NO}_{3}^{-}$ & $62.9 \pm 2.2$ & $0.50 \%$ & $177.1 \pm 8.5$ & $0.50 \%$ & $112.3 \pm 1.5$ \\
\hline \multirow[t]{7}{*}{$\mathrm{CH}_{3} \mathrm{COO}^{-}$} & $78.0 \pm 4.8$ & $0.70 \%$ & $173.9 \pm 7.9$ & $0.70 \%$ & $114.2 \pm 4.9$ \\
\hline & & $1.0 \%$ & $144.3 \pm 3.5$ & $1.0 \%$ & $133.3 \pm 1.9$ \\
\hline & & $2.0 \%$ & $138.7 \pm 3.4$ & $2.0 \%$ & $108.5 \pm 3.7$ \\
\hline & & $4.0 \%$ & $136.4 \pm 3.8$ & $4.0 \%$ & $107.2 \pm 3.6$ \\
\hline & & $6.0 \%$ & $115.9 \pm 10.6$ & $6.0 \%$ & $106.7 \pm 8.8$ \\
\hline & & $8.0 \%$ & $108.1 \pm 8.6$ & $8.0 \%$ & $111.9 \pm 2.4$ \\
\hline & & $10.0 \%$ & $95.5 \pm 12.2$ & $10 \%$ & $105.8 \pm 7.3$ \\
\hline \multicolumn{2}{|c|}{ Detergent (1\%) } & \multicolumn{2}{|c|}{ Chelating agent (10 mM) } & \multicolumn{2}{|c|}{ Modifying agent (1 mM) } \\
\hline Control & $100.0 \pm 2.5$ & Control & $100.0 \pm 2.5$ & Control & $100.0 \pm 2.5$ \\
\hline Tween 20\% & $82.1 \pm 6.3$ & EDTA & $80.7 \pm 5.7$ & DEPC & $85.4 \pm 7.9$ \\
\hline Tween 80\% & $79.5 \pm 5.4$ & & & & \\
\hline SDS & $10.9 \pm 1.9$ & & & & \\
\hline
\end{tabular}

with 8 h (Figure 2A). Consequently, a central composite design (CCD) coupled with response surface methodology (RSM) was performed in order to evaluate the effect of the experimental conditions "reaction time" and "enzyme concentration" on the enzymatic hydrolysis of macaw pulp oil. The enzyme concentration ranged from 0.5 to $1.8 \mathrm{mg} / \mathrm{ml}$, according to preliminary tests. The range of reaction time was defined from 1 to $15 \mathrm{~h}$, in which the center point was set at $8 \mathrm{~h}$. Table 2 shows the experiments that were performed according to the CCD matrix, as well as the hydrolysis degree obtained for each experiment. The hydrolysis degree varied from $39 \%$ to $77 \%$, in the evaluated range. The highest hydrolysis degree was obtained using $1.69 \mathrm{mg} / \mathrm{ml}$ and reaction time of 13:47 $\mathrm{h}$ (run 4 ). With the experimental results, a quadratic regression model was fitted [Eq. (2)], by eliminating the parameters which were not significant (values of $p>0.05$ ). Thus, the statistical model obtained [Eq. (2)] describes the effect of the significant parameters on the hydrolysis degree $(y)$.

$$
y(\%)=67.63+5.60 X_{C}+11.97 X_{t}-5.86 X_{C}^{2}
$$

where $X_{C}$ and $X_{t}$ correspond to coded values for lipase concentration and reaction time, respectively. Eq. (2) had a correlation coefficient $R^{2}$ of 0.9393 and adjusted $R^{2}$ of 0.9166 , which means that the statistical model accurately describes the correlation between the actual and predicted responses (Jun et al., 2019). The analysis of variance (ANOVA) for the model is presented in the Supplementary Material Section (Supplementary Table S5).

The regression coefficients of Eq. (2) show that reaction time $\left(X_{t}\right)$ was the most significant parameter on the hydrolytic degree, with a coefficient of 11.97 , followed by the quadratic effect of enzyme concentration $\left(X_{C}^{2}\right)$, with a coefficient of 5.86, and, finally, the linear effect of enzyme concentration $\left(X_{C}\right)$, with 5.60. The interaction between the parameters was not significant. Furthermore, the signals of the regression coefficient show that all linear parameters positively affect the response of the process. In contrast, the quadratic term of enzyme concentration negatively affects hydrolytic activity.

Comparing the experiments in which ReLip concentration was fixed and the time of reaction was changed (runs 1-2, 

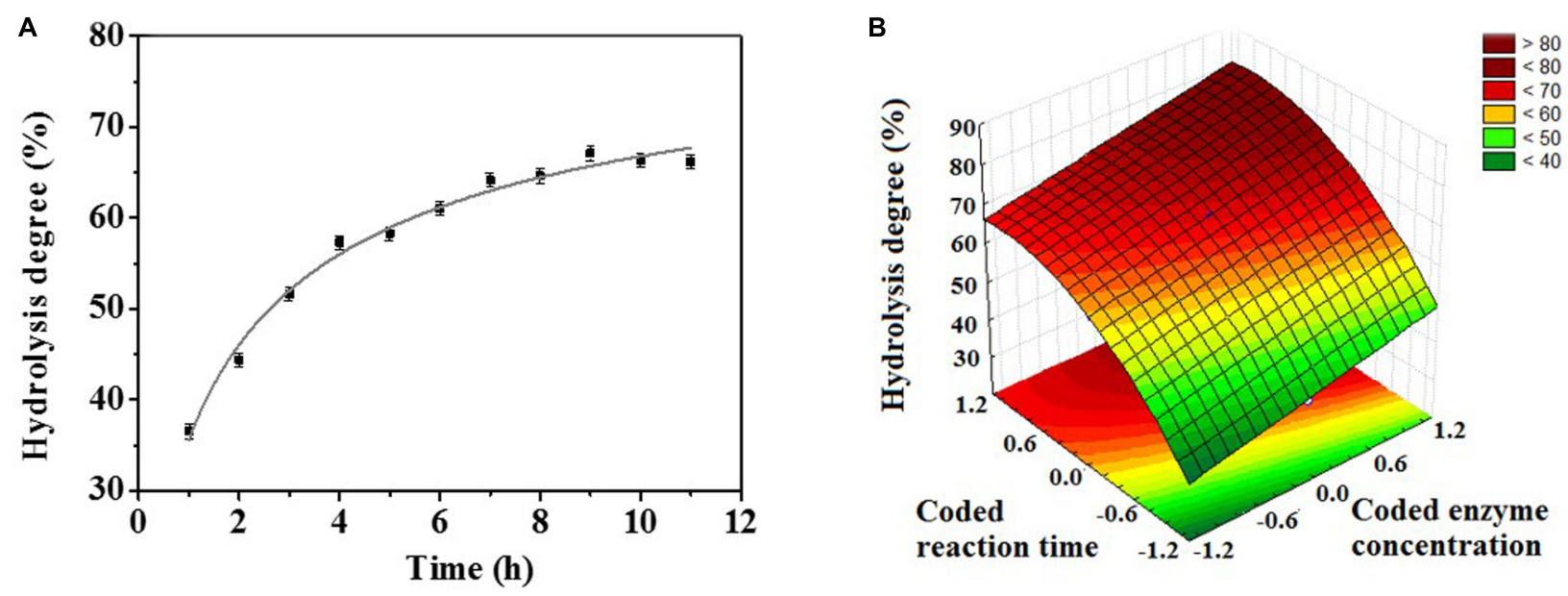

FIGURE 2 | (A) Kinetic profile of macaw oil hydrolysis (5 wt\%), at $35^{\circ} \mathrm{C}, \mathrm{pH} 4.0$, and enzyme concentration of $1 \mathrm{mg} / \mathrm{ml}$. (B) Response surface for macaw oil hydrolysis degree as a function of coded reaction time $\left(X_{t}\right)$ and coded enzyme concentration $\left(X_{C}\right)$. Experimental conditions: $35^{\circ} \mathrm{C}$ and $\mathrm{pH} 4.0$.

3-4, 7-8-center points), it is possible to observe the positive effect of reaction time on hydrolysis degree. Raising the variable from level -1 to level +1 promoted an increase of 1.35fold in the hydrolysis degree. In addition, comparing runs where the time of reaction was fixed and enzyme concentration was changed (runs 1-3, 2-4, 5-6-center points), it is possible to observe that an increase in enzyme concentration also promoted an increase in the hydrolysis degree. However, this effect was less pronounced. From level -1 to level +1 , an increase of 1.18-fold in the hydrolysis degree occurred. The effect of the independent variables on hydrolysis degree can also be observed at the $3 \mathrm{D}$ response surface plot (Figure 2B). It is possible to note that the region with the highest hydrolysis degree is obtained at the highest values of enzyme concentration and time of reaction, in accordance with the positive effect obtained in the statistic equation [Eq. (2)].

In order to maximize the hydrolysis degree, a canonical analysis for the complete regression model was applied. The canonical model is presented in Eq. (3). All characteristic roots $\left(\lambda_{1}\right.$ and $\left.\lambda_{2}\right)$ presented negative signals, which means that a maximum stationary point was obtained. The optimal conditions suggested by the optimization were $3.0 \mathrm{mg} / \mathrm{ml}$ of enzyme (coded value 3.43 ) and $14 \mathrm{~h} 06 \mathrm{~min}$ of reaction (coded value 1.05), with a predicted hydrolysis degree of $84 \%$. An experimental validation was conducted. The experiments at the optimal conditions were performed in duplicate. A hydrolysis degree of $81.47 \%$ was obtained, with a final FFA content of $92 \%$, confirming the result predicted by the canonical analysis.

$$
y=84.04-5.86 w_{1}^{2}-0.83 w_{2}^{2}
$$

The results obtained in the present work, which were hydrolysis degree of $81.5 \%$ and hydrolyzate with final FFA of $92.0 \%$, are very promising, since ReLip presented similar results on the hydrolysis of macaw pulp oil to those conducted with commercial and vegetable lipases (Table 3 ). As previously mentioned, macaw
TABLE 2 | Experimental design for the hydrolysis of macaw oil, with uncoded values of lipase concentration $(C)$ and reaction time $(t)$ and hydrolysis degree (\%) obtained.

\begin{tabular}{lccc}
\hline Run & $\begin{array}{c}\text { Lipase concentration } \\
(\mathbf{m g} / \mathbf{m l})\end{array}$ & Reaction time (h) & $\begin{array}{c}\text { Hydrolysis } \\
\text { degree (\%) }\end{array}$ \\
\hline 1 & 0.61 & $2 \mathrm{~h} 12 \mathrm{~min}$ & $48.25 \pm 0.26$ \\
2 & 0.61 & $13 \mathrm{~h} 47 \mathrm{~min}$ & $66.80 \pm 0.03$ \\
3 & 1.69 & $2 \mathrm{~h} 12 \mathrm{~min}$ & $58.34 \pm 0.06$ \\
4 & 1.69 & $13 \mathrm{~h} 47 \mathrm{~min}$ & $77.35 \pm 1.14$ \\
5 & 0.50 & $8 \mathrm{~h}$ & $57.65 \pm 1.38$ \\
6 & 1.80 & $8 \mathrm{~h}$ & $72.68 \pm 0.15$ \\
7 & 1.15 & $1 \mathrm{~h}$ & $39.06 \pm 0.33$ \\
8 & 1.15 & $15 \mathrm{~h}$ & $76.55 \pm 0.76$ \\
9 & 1.15 & $8 \mathrm{~h}$ & $68.77 \pm 1.16$ \\
10 & 1.15 & $8 \mathrm{~h}$ & $69.11 \pm 0.79$ \\
11 & 1.15 & $8 \mathrm{~h}$ & $68.13 \pm 0.67$ \\
12 & 1.15 & $8 \mathrm{~h}$ & $68.30 \pm 1.00$ \\
\hline
\end{tabular}

Experimental conditions: $35^{\circ} \mathrm{C}$ and $\mathrm{pH} 4.0$.

palm is a very productive oleaginous tree, adapted to various types of soil and to semiarid ecosystems (Moura et al., 2009), which avoids conflict with areas used for food production. Additionally, its acidic oil cannot be used as food (Aguieiras et al., 2014), making it a great alternative as feedstock for biofuel production.

\section{ReLip Is Highly Thermo-Tolerant Under Acidic Conditions and in the Presence of Organic Solvents}

To evaluate the conformational stability of ReLip under harsh conditions such as low $\mathrm{pH}$ and the presence of organic solvents, the secondary structure profile was monitored by circular dichroism (CD) in a broad temperature range. CD analyses showed that ReLip presents a typical $\alpha$-helical profile, with minimum molar ellipticities at 208 and $222 \mathrm{~nm}$. Furthermore, at 
TABLE 3 | Comparison of final free fatty acid obtained from the hydrolysis of macaw pulp oil, using lipases from different sources.

\begin{tabular}{|c|c|c|c|}
\hline Catalyst & Conditions of the hydrolysis reaction & $\begin{array}{l}\text { Final free fatty acid of } \\
\text { hydrolyzate (\%) }\end{array}$ & References \\
\hline Lipase from Rasamsonia emersonii & $\begin{array}{l}35^{\circ} \mathrm{C}, \mathrm{pH} 4.0 \text {, oil concentration of } 5 \% \mathrm{~m} / \mathrm{m} \text {, enzyme concentration } \\
\text { of } 3 \mathrm{mg} / \mathrm{ml}, 14 \text { h of reaction }\end{array}$ & $92 \%$ & This work \\
\hline Enzyme extract from the castor bean & $\begin{array}{l}35^{\circ} \mathrm{C}, \mathrm{pH} 4.5,25 \% \text { oil-water mass concentration and } 288 \mathrm{U} \text {, } \\
4 \mathrm{~h} \text { of reaction }\end{array}$ & $83 \%$ & Machado (2017) \\
\hline $\begin{array}{l}\text { Enzyme extract from dormant castor } \\
\text { seeds }\end{array}$ & $\begin{array}{l}30^{\circ} \mathrm{C}, \mathrm{pH} 4.0 \text {, oil concentration of } 50 \% \mathrm{v} / \mathrm{v} \text {, enzyme concentration } \\
\text { of } 2.5 \% \mathrm{~m} / \mathrm{v}, 6 \text { h of reaction }\end{array}$ & $99.6 \%$ & Aguieiras et al. (2014) \\
\hline $\begin{array}{l}\text { Enzymatic extract from dormant castor } \\
\text { bean seeds }\end{array}$ & $\begin{array}{l}35^{\circ} \mathrm{C}, \mathrm{pH} 4.5 \text {, mass ratio oil:buffer of } 35 \% \mathrm{~m} / \mathrm{m} \text {, enzyme } \\
\text { concentration of } 6 \% \mathrm{~m} / \mathrm{m}, 110 \text { min of reaction }\end{array}$ & $100 \%$ & Bressani et al. (2015) \\
\hline $\begin{array}{l}\text { Commercial lipases: Lipozyme RM IM, } \\
\text { Lipozyme TL IM, and Lipozyme } 435 .\end{array}$ & $\begin{array}{l}55^{\circ} \mathrm{C}, \mathrm{pH} 8.0 \text {, mass ratio oil:buffer of } 2: 1 \text {, Lipozyme RM IM } \\
\text { concentration of } 15 \% \text { and } 6 \text { h of reaction }\end{array}$ & $82 \%$ & Raspe et al. (2013) \\
\hline
\end{tabular}

A

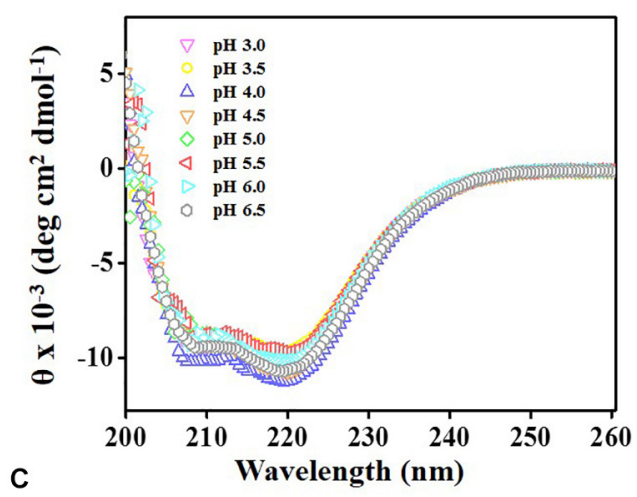

C

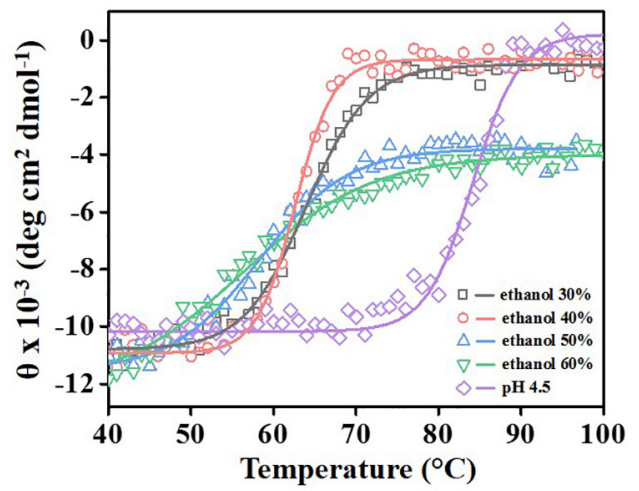

B

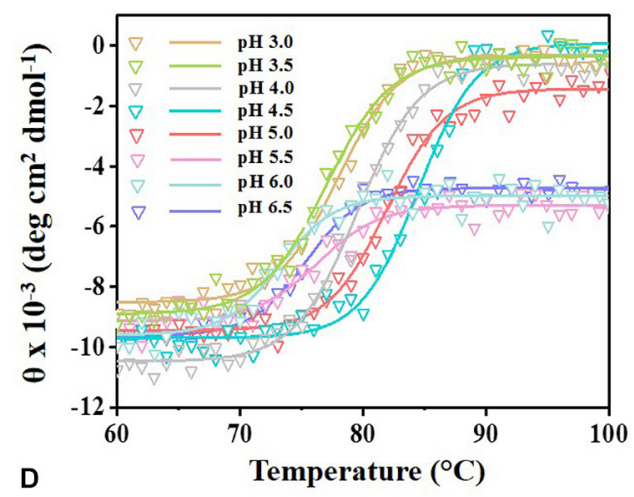

D

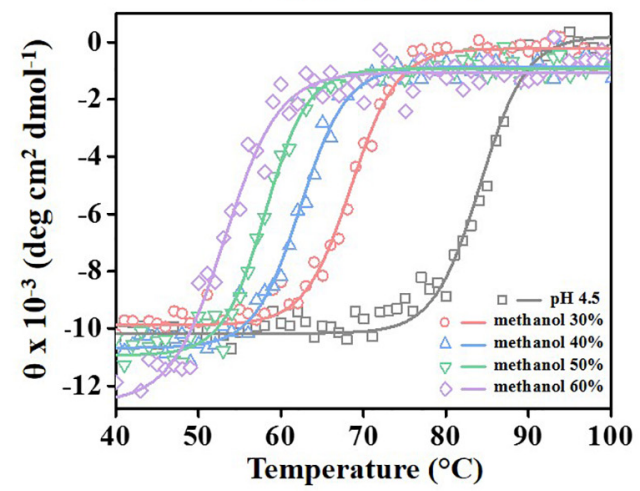

FIGURE 3 | The far-UV averaged circular dichroism spectra of ReLip, monitored at $20^{\circ} \mathrm{C}$ (A) at different pH conditions (from 3 to 6.5). (B) Thermal denaturation profile of ReLip from $20^{\circ} \mathrm{C}$ to $100^{\circ} \mathrm{C}$, monitored at $220 \mathrm{~nm}$ by circular dichroism spectroscopy at different pH conditions (from 3 to 6.5) and in the presence of different concentrations (from $30 \%$ to $60 \% \mathrm{v} / \mathrm{v}$ ) of (C) ethanol and (D) methanol. The melting temperature $\left(T_{m}\right)$ varied from $73^{\circ} \mathrm{C}$ to $84^{\circ} \mathrm{C}$ for different pHs; maximum values were obtained at $\mathrm{pH} 4.5$ and 5.0 , with $T_{m}$ of $84^{\circ} \mathrm{C}$ and $82^{\circ} \mathrm{C}$, respectively. For ethanol: the melting temperature $\left(T_{m}\right)$ varied from $56^{\circ} \mathrm{C}$ to $64^{\circ} \mathrm{C}$ at different concentrations, in which the maximum value $\left(64^{\circ} \mathrm{C}\right)$ was obtained with $30 \%$ of ethanol. For methanol: the melting temperature $\left(T_{\mathrm{m}}\right)$ varied from $54^{\circ} \mathrm{C}$ to $68^{\circ} \mathrm{C}$ at different concentrations, in which the maximum value $\left(68^{\circ} \mathrm{C}\right)$ was obtained with $30 \%$ of methanol.

different $\mathrm{pH}$ conditions (from 3 to 6.5 ), the secondary structure of the enzyme remained practically unchanged (Figure 3A). The analysis of the melting temperature $\left(T_{m}\right)$, by the measurement of thermal denaturation profiles at $220 \mathrm{~nm}$ (Figure 3B), revealed that the $T_{m}$ varied from $73^{\circ} \mathrm{C}$ to $84^{\circ} \mathrm{C}$ for different $\mathrm{pHs}$, with the maximum values obtained at $\mathrm{pH} 4.5$ and 5.0 , with a $T_{m}$ of $84^{\circ} \mathrm{C}$ and $82^{\circ} \mathrm{C}$, respectively. These results corroborate the data obtained previously, in which higher activities were observed under similar conditions. Thermo-tolerant lipases such as Bacillus thermoamylovorans, Thermomyces lanuginosus, and Geobacillus thermoleovorans have been reported in the literature, with thermal stability up to approximately $60^{\circ} \mathrm{C}$ (Sun et al., 2016; Mehta et al., 2017). ReLip shows $T_{m}$ values higher than other lipases considered thermostable, with an advantage of featuring high stability under acidic conditions, which is extremely desirable for many biotechnological applications, especially for 
biofuel production from crude or residual vegetable oils, which present high FFA contents.

The conformational changes in the secondary structures were also evaluated with ReLip in the presence of organic solvents such as methanol and ethanol, compounds that are widely used in the biofuel industries. Surprisingly, ReLip had its secondary structure unaffected in the presence of up to $60 \%$ ethanol and methanol at room temperature (Supplementary Figures S4A,B), which confirms its ability to tolerate organic solvents in high quantities, similar to that used in the industry. Figures 3C,D show the thermal denaturation profiles of ReLip in the presence of these organic solvents. Changes in the enzyme thermal stability were observed; $T_{m}$ values decreased as the amount of solvent was increased. In the presence of ethanol, from $30 \%$ to $60 \%, T_{m}$ varied from $64^{\circ} \mathrm{C}$ to $56^{\circ} \mathrm{C}$. In the presence of methanol, it changed from $68^{\circ} \mathrm{C}$ to $54^{\circ} \mathrm{C}$. Despite the decrease detected for both solvents, $T_{m}$ values are significantly high, showing the good thermal stability of the enzyme and its high potential for application in reactions that involve those solvents. The phenomenon of $T_{m}$ reduction in the presence of solvents may occur due to an alteration in the water-solvating layer (caused by organic solvents soluble in water) that surrounds the protein in aqueous solution, which may compromise the structural integrity of the enzyme. In addition, hydrophobic interactions of the structure can be affected by the presence of methanol and ethanol (Kamal et al., 2013; Sharma et al., 2016).

\section{ReLip Has Unique Structural Properties That May Have Contributed to Its Acid and Methanol Tolerance}

Despite a wealth of functional data on lipases, structural and mechanistic information are rather limited, especially for those from fungal origin. This is due to the difficulty of heterologous expression in a soluble and stable form, and the inherent recalcitrance to crystallization processes. The quaternary arrangement required for functional and structural stability is also partially understood with monomeric (Rhizomucor miehei) and dimeric (Thermomyces lanuginosus) lipolytic enzymes reported.

Consequently, the oligomeric arrangement of ReLip was also assessed by DLS (Supplementary Figure S5A) and SAXS (Supplementary Figures S6A,B). DLS analysis revealed that ReLip behaved as a monodisperse population ( $\mathrm{Pd}<15 \%)$ of monomers with an average hydrodynamic radius $(\mathrm{Rh})$ of $3.05 \mathrm{~nm}$. SAXS data showed that ReLip has a gyration radius of $2.4 \mathrm{~nm}$, which is in agreement with DLS data. In addition, the obtained envelope from the SAXS curve showed that the low-resolution structure of ReLip consists of a monomeric globular form that corroborates with the three-dimensional structure obtained by X-ray crystallography (Supplementary Figure S6C).

Aiming to get structural information regarding the interesting functional properties of ReLip, the enzyme was submitted to crystallization tests. The obtained crystal (Supplementary Figure S5B) diffracted to $3.0 \AA$ resolution, and the structure was solved using molecular replacement methods with the lipase from Penicillium cyclopium (PDB: 5CH8, 48.09\% identity) as template. The ReLip structure (PDB: $6 \mathrm{UNV}$ ) presents an $\alpha / \beta$ hydrolase fold and consists of a major eight-stranded mixed $\beta$-sheet, two minor two-stranded $\beta$-sheet arrangements and five $\alpha$-helices (Figure 4). Unlike its orthologs, ReLip lacks the glycosylation site at position 33 , which has a natural mutation with alanine instead of an asparagine. The literature reports that this site is important for the binding and recognition of micelles by TLL but apparently does not interfere in the catalytic activity (Peters et al., 2002). The lack of a glycosylation site in ReLip structure may have contributed to its expression in a folded and stable form in a bacterial organism.

As expected, the catalytic triad of ReLip consists of the residues Ser177, His290, and Asp232, which are fully conserved in other lipases and esterases (Figure 4A). ReLip possesses three disulfide bonds (C67-C72, C53-C300, C135-C138) that are also conserved in TLL (Figure 4). One of them (C135-C138) is located close to the lid subdomain and is present in both lipases and esterases. The C53-C300 disulfide bridge is connecting the $\mathrm{N}$ - and $\mathrm{C}$-termini, and is adjacent to the other $\mathrm{C} 67-\mathrm{C} 72$, conferring high structural stability to ReLip.

Usually, the lipolytic activity of some lipases increases significantly at the critical micelle concentration of the substrate. This phenomenon of interfacial activation is related to the presence of a hydrophobic patch of the lid subdomain that is protected from the solvent adopting a closed conformation (Skjold-Jørgensen et al., 2014; Khan et al., 2017). With the recognition of the substrate, the lid undergoes conformational changes to expose the hydrophobic patch to interact with the substrate. However, in some lipases that have minilids or do not even possess them, the interfacial activation does not occur, but these enzymes still present lipolytic activities. The three-dimensional structure of ReLip (Figure 4C) confirmed the presence of a helical amphipathic lid, indicating that interfacial activation might be involved in ReLip mechanism of substrate binding such as its ortholog TLL. Indeed, in the crystallographic closed conformation of ReLip, the substrate could not be accommodated in the active-site cleft (Supplementary Figure S7), supporting that a conformational change is required for substrate binding. However, to better comprehend the molecular basis of the putative interfacial activation of ReLip, an in-depth investigation is needed.

Lipases are also known by the occurrence of cluster IxxWxxxxxF, which confers a high hydrophobic character to the lid subdomain (Skjold-Jørgensen et al., 2014). The literature shows that the presence of the tryptophan residue is essential for the interfacial activation and substrate binding. ReLip conserves the residues isoleucine and tryptophan, but the residue phenylalanine is replaced by an alanine. FAE also did not conserve the phenylalanine; instead, it has a tyrosine residue, which contributes to make its lid less hydrophobic (Hermoso et al., 2004). The lack of this aromatic residue in ReLip might be associated with the preference for shorter acyl chains compared to TLL, while preserving the ability to cope with water-insoluble substrates. 


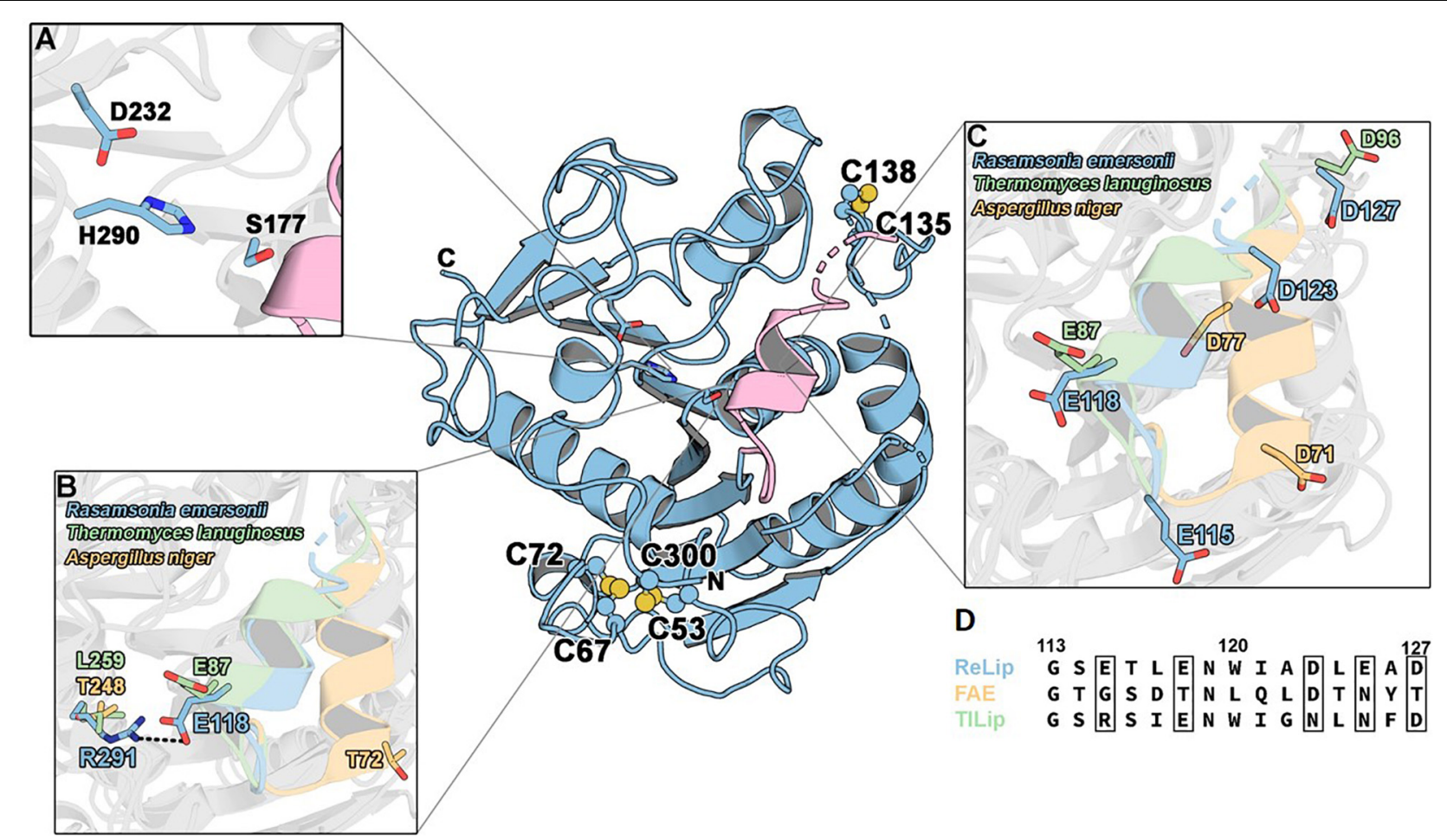

FIGURE 4 | Tridimensional structure of ReLip. (A) Catalytic triad: amino acids Ser177, His290, and Asp232. (B) Presence of a salt bridge formed between Arg291 and Glu118 from the lid subdomain. (C) Lid structures and (D) alignment between the primary sequences of the lids belonging to the lipases from ReLip (this work), TLL (PDB code: 1DT3), and esterase from Aspergillus niger (PDB code: 1USW). The diffraction experiment was performed at SSRL-SLAC beamline BL12-2 with a wavelength of $0.98 \AA$. Crystal diffracted and collected at 2.4- $\AA$ resolution. The phases were obtained by molecular replacement using the three-dimensional structure of MDLA lipase from Penicillium cyclopium (PDB: $5 \mathrm{CH} 8$ ). The refinement was performed to the resolution of $3.0 \AA$ (due to crystallographic anisotropy) using Phenix.

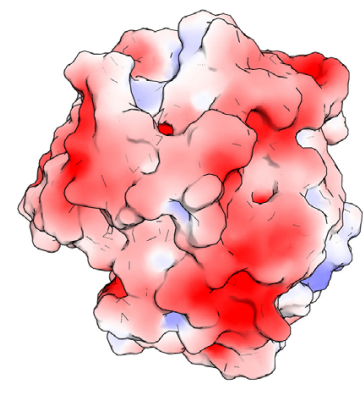

Rిasansonia eñersonil

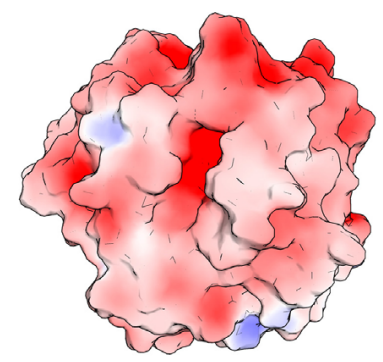

Them

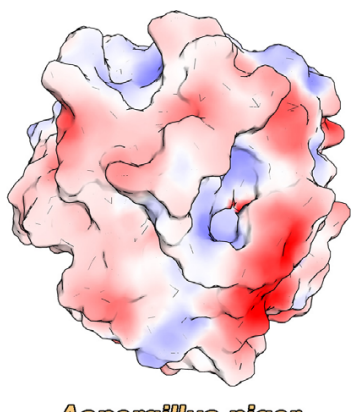

Aspergiollus niger

FIGURE 5 | Electrostatic surface-potential of ReLip (this work), TLL (PDB code: 1DT3), and esterase from Aspergillus niger (PDB code: 1USW), in which regions of negative and positive electrostatic potential are shown in red and blue, respectively.

Another singular feature of ReLip is the presence of a salt bridge formed between Arg291 and Glu118 from the lid subdomain (Figure 4B). This salt bridge is not conserved in other structurally characterized lipases with the lid subdomain such as TLL. In TLL, the glutamate residue is conserved in the lid, but the arginine is substituted by a leucine. The presence of this salt bridge in ReLip implicates in a higher protection of the hydrophobic pocket to bulky solvent, which can be correlated with the high tolerance of ReLip to organic solvents. On the other hand, this salt bridge can represent an additional energetic cost for ReLip to undergo the conformational changes required for substrate binding. The lid belonging to ReLip also has a rare property when compared to other lipases and even esterases, which is the presence of five amino acids with acidic nature, which may have contributed to its robust performance under acidic conditions, thus favoring the hydrolysis of macaw oil, a substrate with high acidity.

Although esterases and lipases have a fully conserved catalytic site, charge distribution on the catalytic interface is reported to be quite unlike (Hermoso et al., 2004). While esterases exhibit 
a more neutral surface charge distribution, lipases have a negatively charged surface. Surface charge distribution has been associated with the better performance of FAE at lower pHs. However, the charge distribution of ReLip largely differs from FAE, resembling that of TLL, despite having a better catalytic activity at lower pHs like FAE. This suggests that other factors aside from surface charge distribution at the catalytic interface are involved in the preference for acidic $\mathrm{pHs}$ for hydrolytic activity of these enzymes (Figure 5).

\section{CONCLUSION}

Several lipases have been studied for the hydrolysis of vegetable oils; nevertheless, only a few, especially those from castor bean seeds, were capable of hydrolyzing macaw oil, an extremely acidic substrate coming from a native palm that is cultivated in a wide variety of soil types. In addition, the enzyme showed other desirable properties for vegetable oil processing, such as tolerance to organic solvents and high temperatures. The crystallographic structure was elucidated indicating the presence of a helical amphipathic lid, which might be involved in a mechanism of interfacial activation with the exposure of the hydrophobic patch for substrate binding. The typical aromatic cluster in the lid IxxWxxxxx is not fully conserved in ReLip with the natural mutation of the phenylalanine by an alanine. It decreases the hydrophobicity of the lid subdomain and is associated with the preference of short acyl chains, although preserving catalytic activity on insoluble substrates. The presence of a salt bridge between the lid and the vicinity of the active-site cleft confers a higher protection of the hydrophobic active site to bulky solvent, which might explain the tolerance of ReLip to organic solvents.

\section{DATA AVAILABILITY STATEMENT}

The atomic coordinates and structure factors of ReLip were deposited in the Protein Data Bank (http://ww.pdb.org/) under accession ID 6UNV. The original contributions presented in the study are included in the article/Supplementary Material.

\section{AUTHOR CONTRIBUTIONS}

LR, MS, NM, and CS carried out the expression and purification of ReLip and the oil hydrolysis reactions. RM and NM performed

\section{REFERENCES}

Adams, P. D., Afonine, P. V., Bunkóczi, G., Chen, V. B., Davis, I. W., Echols, N., et al. (2010). PHENIX: a comprehensive Python-based system for macromolecular structure solution. Acta Crystallogr. Sect. D Biol. Crystallogr. 66, 213-221. doi: 10.1107/S0907444909052925

Aguieiras, E. C. G., Cavalcanti-Oliveira, E. D., De Castro, A. M., Langone, M. A. P., and Freire, D. M. G. (2014). Biodiesel production from Acrocomia aculeata acid oil by (enzyme/enzyme) hydroesterification process: use of vegetable lipase and fermented solid as low-cost biocatalysts. Fuel 135, 315-321. doi: 10.1016/j.fuel. 2014.06.069 the functional experiments using synthetic substrates. NM performed the DLS analyses. MS carried out the CD experiments. PV, MM, and LZ designed and performed the crystallization trials, structure solution and refinement, and structural and SAXS analyses. $\mathrm{LR}, \mathrm{BK}, \mathrm{HC}$, and $\mathrm{AB}$ contributed with the design of the experiments and with the analysis, treatment and discussion of the data obtained. LR wrote the article. LZ directed the overall study, analyzed the data, and wrote the manuscript. All authors read and approved the final manuscript.

\section{FUNDING}

This work was supported by grants from the São Paulo Research Foundation (FAPESP) (grant \#2016/50403-2; grant \#2015/26982-0; grant \#2018/04897-9; grant \#2018/10517-4, and grant \#2019/08855-1) and by LNBR-CNPEM.

\section{ACKNOWLEDGMENTS}

We gratefully thank the Brazilian Synchrotron Light Laboratory (LNLS, CNPEM, Campinas, Brazil) for the use of D01A-SAXS2 beamline; the Biosciences National Laboratory (LNBio, CNPEM, Campinas, Brazil) for the automated crystallization facility (Robolab); the Stanford Synchrotron Radiation Lightsource, SLAC National Accelerator Laboratory (Menlo Park, CA, United States), supported by the U.S. Department of Energy, Office of Science, Office of Basic Energy Sciences, under Contract No. DE-AC02-76SF00515 and the Macromolecular Analysis Laboratory (LAM) and Metabolomics Laboratory (LabMet) (LNBR-CNPEM, Campinas, Brazil) for the use of facilities. The SSRL Structural Molecular Biology Program is supported by the DOE Office of Biological and Environmental Research and by the National Institutes of Health, National Institute of General Medical Sciences (P41GM103393). The contents of this publication are solely the responsibility of the authors and do not necessarily represent the official views of NIGMS or NIH.

\section{SUPPLEMENTARY MATERIAL}

The Supplementary Material for this article can be found online at: https://www.frontiersin.org/articles/10.3389/fbioe. 2020.00304/full\#supplementary-material

Amini, Z., Ilham, Z., Ong, H. C., Mazaheri, H., and Chen, W. H. (2017). State of the art and prospective of lipase-catalyzed transesterification reaction for biodiesel production. Energy Convers. Manag. 141, 339-353. doi: 10.1016/j.enconman. 2016.09.049

AOCS (2005). "Fatty acid composition by gas chromatography," in Official Methods and Recommended Practices of the American Oil Chemists' Society, ed. R. Walker (Champaign, IL: AOCS Press).

Avelar, M. H. M., Cassimiro, D. M. J., Santos, K. C., Domingues, R. C. C., De Castro, H. F., and Mendes, A. A. (2013). Hydrolysis of vegetable oils catalyzed by lipase extract powder from dormant castor bean seeds. Ind. Crops Prod. 44, 452-458. doi: 10.1016/j.indcrop.2012.10.011 
Bajaj, A., Lohan, P., Jha, P. N., and Mehrotra, R. (2010). Biodiesel production through lipase catalyzed transesterification: an overview. J. Mol. Catal. B Enzym. 62, 9-14. doi: 10.1016/j.molcatb.2009.09.018

Belhaj, D. I., Belghith, H., Gargouri, A. F., and Romdhane, Z. (2011). Esterification activity and stability of Talaromyces thermophilus lipase immobilized onto chitosan. J. Mol. Catal. B Enzym. 68, 230-239. doi: 10.1016/j.molcatb.2010.11. 010

Beller, H. R., Goh, E. B., and Keasling, J. D. (2010). Genes involved in longchain alkene biosynthesis in Micrococcusluteus. Appl. Environ. Microbiol. 76, 1212-1223. doi: 10.1128/AEM.02312-09

Bora, P. S., and Rocha, R. V. M. (2004). Macaiba palm: fatty and amino acids composition of fruits macaíba: composición de aminoácidos y ácidos grasos de frutos macaíba: composición de aminoácidos e ácidos graxos de froitos. Cienc. Tecnol. Aliment. 4, 158-162. doi: 10.1080/1135812040948 7755

Box, G., and Tiao, G. (1977). A canonical analysis of multiple time series. Biometrika 64, 355-365.

Bressani, A. P. P., Garcia, K. C. A., Hirata, D. B., and Mendes, A. A. (2015). Production of alkyl esters from macaw palm oil by a sequential hydrolysis/esterification process using heterogeneous biocatalysts: optimization by response surface methodology. Bioprocess Biosyst. Eng. 38, 287-297. doi: 10.1007/s00449-014-1267-5

Chen, L., Li, H., Fu, J., Miao, C., Lv, P., and Yuan, Z. (2016). Catalytic hydroprocessing of fatty acid methyl esters to renewable alkane fuels over Ni/HZSM-5 catalyst. Catal. Today 259, 266-276. doi: 10.1016/j.cattod.2015.08. 023

Choi, W. C., Myung, H. K., Ro, H. S., Sang, R. R., Oh, T. K., and Lee, J. K. (2005). Zinc in lipase L1 from Geobacillus stearothermophilus L1 and structural implications on thermal stability. FEBS Lett. 579, 3461-3466. doi: 10.1016/j. febslet.2005.05.016

Ciconini, G., Favaro, S. P., Roscoe, R., Miranda, C. H. B., Tapeti, C. F., Miyahira, M. A. M., et al. (2013). Biometry and oil contents of Acrocomia aculeata fruits from the Cerrados and Pantanal biomes in Mato Grosso do Sul, Brazil. Ind. Crops Prod. 45, 208-214. doi: 10.1016/j.indcrop.2012.12.008

da Conceição, L. R. V., Carneiro, L. M., Giordani, D. S., and de Castro, H. F. (2017). Synthesis of biodiesel from macaw palm oil using mesoporous solid catalyst comprising 12-molybdophosphoric acid and niobia. Renew. Energy 113, 119-128. doi: 10.1016/j.renene.2017.05.080

Derewenda, U., Derewenda, Z. S., Brzozowski, A. M., and Lawson, D. M. (1992). Catalysis at the interface: the anatomy of a conformational change in a triglyceride lipase. Biochemistry 31, 1532-1541. doi: 10.1021/bi001 $20 \mathrm{a} 034$

Evans, P. (2006). Scaling and assessment of data quality. Acta Crystallogr. Sect. D Biol. Crystallogr. 62, 72-82. doi: 10.1107/S0907444905036693

Evans, P. R. (2011). An introduction to data reduction: space-group determination, scaling and intensity statistics. Acta Crystallogr. Sect. D Biol. Crystallogr. 67, 282-292. doi: 10.1107/S090744491003982X

Glogauer, A., Martini, V. P., Faoro, H., Couto, G. H., Müller-Santos, M., Monteiro, R. A., et al. (2011). Identification and characterization of a new true lipase isolated through metagenomic approach. Microb. Cell Fact. 10:54. doi: 10.1186/ 1475-2859-10-54

Gosselink, R. W., Hollak, S. A. W., Chang, S.-W., van Haveren, J., de Jong, K. P., Bitter, J. H., et al. (2013). Reaction pathways for the deoxygenation of vegetable oils and related model compounds. ChemSusChem 6, 1576-1594. doi: 10.1002/ cssc. 201300370

Goswami, D., Basu, J. K., and De, S. (2013). Lipase applications in oil hydrolysis with a case study on castor oil: a review. Crit. Rev. Biotechnol. 33, 81-96. doi: 10.3109/07388551.2012.672319

Gruber, C. C., and Pleiss, J. (2012). Lipase B from Candida antarctica binds to hydrophobic substrate-water interfaces via hydrophobic anchors surrounding the active site entrance. J. Mol. Catal. B Enzym. 84, 48-54. doi: 10.1016/j. molcatb.2012.05.012

Gudmundsson, M., Hansson, H., Karkehabadi, S., and Larsson, A. (2016). Structural and functional studies of the glycoside hydrolase family $3 \mathrm{~b}$ glucosidase Cel3A from the moderately thermophilic fungus Rasamsonia emersonii research papers. Acta Crystallogr. Sect. D Struct. Biol. 72, 860-870. doi: $10.1107 /$ S2059798316008482
Hammersley, A. P. (2016). FIT2D: A multi-purpose data reduction, analysis and visualization program. J. Appl. Crystallogr. 49, 646-652. doi: 10.1107/ S1600576716000455

Herman, N. A., and Zhang, W. (2016). Enzymes for fatty acid-based hydrocarbon biosynthesis. Curr. Opin. Chem. Biol. 35, 22-28. doi: 10.1016/j.cbpa.2016.08. 009

Hermoso, J. A., Sanz-Aparicio, J., Molina, R., Juge, N., González, R., and Faulds, C. B. (2004). The crystal structure of feruloyl esterase A from Aspergillus niger suggests evolutive functional convergence in feruloyl esterase family. J. Mol. Biol. 338, 495-506. doi: 10.1016/j.jmb.2004.03.003

Hiol, A., Jonzo, M. D., Rugani, N., Druet, D., Sarda, L., and Comeau, L. C. (2000). Purification and characterization of an extracellular lipase from a thermophilic Rhizopus oryzae strain isolated from palm fruit. Enzyme Microb. Technol. 26, 421-430. doi: 10.1016/S0141-0229(99)00173-8

Hwang, H. T., Qi, F., Yuan, C., Zhao, X., Ramkrishna, D., Liu, D., et al. (2014). Lipase-catalyzed process for biodiesel production: protein engineering and lipase production. Biotechnol. Bioeng. 111, 639-653. doi: 10.1002/bit.25162

Jaeger, K.-E., Dijkstra, B. W., and Reetz, M. T. (2002). Bacterial Biocatalysts: molecular biology, three-dimensional structures, and biotechnological applications of lipases. Annu. Rev. Microbiol. 53, 315-351. doi: 10.1146/annurev.micro.53.1.315

Jun, L. Y., Mubarak, N. M., Yon, L. S., Bing, C. H., Khalid, M., Jagadish, P., et al. (2019). Immobilization of peroxidase on functionalized MWCNTsBuckypaper/Polyvinyl alcohol nanocomposite membrane. Sci. Rep. 9:2215. doi: 10.1038/s41598-019-39621-4

Kabsch, W. (2010). XDS. Acta Crystallogr. Sect. D Biol. Crystallogr. 66, 125-132. doi: $10.1107 /$ S0907444909047337

Kamal, Z., Yedavalli, P., Deshmukh, M. V., and Rao, N. M. (2013). Lipase in aqueous-polar organic solvents: activity, structure, and stability. Protein Sci. 22, 904-915. doi: 10.1002/pro.2271

Karatzos, S., van Dyk, J. S., McMillan, J. D., and Saddler, J. (2017). Drop-in biofuel production via conventional (lipid/fatty acid) and advanced (biomass) routes. Part I Drop-in biofuel production via conventional and advanced routes. Biofuels Bioprod. Bioref. 11, 344-362. doi: 10.1002/bbb

Khan, F. I., Lan, D., Durrani, R., Huan, W., Zhao, Z., and Wang, Y. (2017). The lid domain in lipases: structural and functional determinant of enzymatic properties. Front. Bioeng. Biotechnol. 5:16. doi: 10.3389/fbioe.2017.00016

Khan, S., Kay Lup, A. N., Qureshi, K. M., Abnisa, F., Wan Daud, W. M. A., and Patah, M. F. A. (2019). A review on deoxygenation of triglycerides for jet fuel range hydrocarbons. J. Anal. Appl. Pyrolysis 140, 1-24. doi: 10.1016/j.jaap.2019. 03.005

Kim, S. K., Han, J. Y., Lee, H. S., Yum, T., Kim, Y., and Kim, J. (2014). Production of renewable diesel via catalytic deoxygenation of natural triglycerides: comprehensive understanding of reaction intermediates and hydrocarbons. Appl. Energy 116, 199-205. doi: 10.1016/j.apenergy.2013.11.062

Knoot, C. J., and Pakrasi, H. B. (2019). Diverse hydrocarbon biosynthetic enzymes can substitute for olefin synthase in the cyanobacterium Synechococcus sp. PCC 7002. Sci. Rep. 9:1360. doi: 10.1038/s41598-018-38124-y

Kozin, M. B., and Svergun, D. I. (2001). Automated matching of high- and low-resolution structural models. J. Appl. Crystallogr. 34, 33-41. doi: 10.1107/ S0021889800014126

Lan, D., Wang, Q., Xu, J., Zhou, P., Yang, B., and Wang, Y. (2015). Residue Asn277 affects the stability and substrate specificity of the SMG1 lipase from Malassezia globosa. Int. J. Mol. Sci. 16, 7273-7288. doi: 10.3390/ijms 16047273

Lebedev, A. A., and Isupov, M. N. (2014). Space-group and origin ambiguity in macromolecular structures with pseudo-symmetry and its treatment with the program Zanuda. Acta Crystallogr. Sect. D Biol. Crystallogr. 70, 2430-2443. doi: $10.1107 / S 1399004714014795$

Li, F., Yang, K., Xu, Y., Qiao, Y., Yan, Y., and Yan, J. (2019). A genetically-encoded synthetic self-assembled multienzyme complex of lipase and P450 fatty acid decarboxylase for efficient bioproduction of fatty alkenes. Bioresour. Technol. 272, 451-457. doi: 10.1016/j.biortech.2018.10.067

Lopes, D. C., Steidle Neto, A. J., Mendes, A. A., and Pereira, D. T. V. (2013). Economic feasibility of biodiesel production from Macauba in Brazil. Energy Econ. 40, 819-824. doi: 10.1016/j.eneco.2013.10.003

Machado, S. A. (2017). "Production of biodiesel from macaw palm (Acrocomia aculeata) oil with high acidity employing hydroesterification process," in 
Proceedings of the 15th International Conference on Environmental Science and Technology, Rhodes.

Martínez, P. M., Appeldoorn, M. M., Gruppen, H., and Kabel, M. A. (2016). The twoRasamsonia emersonii $\alpha$-glucuronidases, ReGH67 and ReGH115, show a different mode-of-action towards glucuronoxylan and glucuronoxylooligosaccharides. Biotechnol. Biofuels 9:105. doi: 10.1186/s13068-016-0519-9

Maruyama, T., Nakajima, M., Ichikawa, S., Nabetani, H., Furusaki, S., and Seki, M. (2000). Oil-water interfacial activation of lipase for interesterification of triglyceride and fatty acid. J. Am. Oil Chem. Soc. 77, 1121-1126. doi: 10.1007/ s11746-000-0176-4

Mehta, A., Bodh, U., and Gupta, R. (2017). Fungal lipases: a review. J. Biotech Res. $8,58-77$.

Moura, E. F., Motoike, S. Y., Ventrella, M. C., de Sá Júnior, A. Q., and Carvalho, M. (2009). Somatic embryogenesis in macaw palm (Acrocomia aculeata) from zygotic embryos. Sci. Hortic. 119, 447-454. doi: 10.1016/j.scienta.2008.08.033

Muto, S., and Beevers, H. (1974). Lipase activities in castor bean endosperm during germination. Plant Physiol. 54, 23-28. doi: 10.1104/pp.54.1.23

Norjannah, B., Ong, H. C., Masjuki, H. H., Juan, J. C., and Chong, W. T. (2016). Enzymatic transesterification for biodiesel production: a comprehensive review. RSC Adv. 6, 60034-60055. doi: 10.1039/c6ra08062f

Ory, R. L., Angelo, J. S. A., and Altschul, A. M. (1962). The acid lipase of the castor bean. Properties and substrate specificity. J. Lipid Res. 3, 99-105.

Papaparaskevas, D., Christakopoulos, P., Kekos, D., and Macris, B. J. (1992). Optimizing production of extracellular lipase from Rhodotorula glutinis. Biotechnol. Lett. 14, 397-402.

Pattanaik, B. P., and Misra, R. D. (2017). Effect of reaction pathway and operating parameters on the deoxygenation of vegetable oils to produce diesel range hydrocarbon fuels: a review. Renew. Sustain. Energy Rev. 73, 545-557. doi: 10.1016/j.rser.2017.01.018

Peters, G. H., Svendsen, A., Langberg, H., Vind, J., Patkar, S. A., and Kinnunen, P. K. J. (2002). Glycosylation of Thermomyces lanuginosa lipase enhances surface binding towards phospholipids, but does not significantly influence the catalytic activity. Colloids Surf. B Biointerfaces 26, 125-134. doi: 10.1016/S09277765(02)00030-9

Pires, T. P., dos Santos Souza, E., Kuki, K. N., and Motoike, S. Y. (2013). Ecophysiological traits of the macaw palm: a contribution towards the domestication of a novel oil crop. Ind. Crops Prod. 44, 200-210. doi: 10.1016/j. indcrop.2012.09.029

Priyanka, P., Kinsella, G., Henehan, G. T., and Ryan, B. J. (2019). Isolation, purification and characterization of a novel solvent stable lipase from Pseudomonas reinekei. Protein Expr. Purif. 153, 121-130. doi: 10.1016/j.pep. 2018.08.007

Raspe, D. T., Cardozo Filho, L., and da Silva, C. (2013). Effect of additives and process variables on enzymatic hydrolysis of macauba kernel oil (Acrocomia aculeata). Int. J. Chem. Eng. 2013, 1-8. doi: 10.1155/2013/438270

Reis, P., Holmberg, K., Watzke, H., Leser, M. E., and Miller, R. (2009). Lipases at interfaces: a review. Adv. Colloid Interface Sci. 14, 237-250. doi: 10.1016/j.cis. 2008.06.001

Rhee, J. K., Ahn, D. G., Kim, Y. G., and Oh, J. W. (2005). New thermophilic and thermostable esterase with sequence similarity to the hormone-sensitive lipase family, cloned from a metagenomic library. Appl. Environ. Microbiol. 71, 817-825. doi: 10.1128/AEM.71.2.817-825.2005

Romero, C. M., Baigori, M. D., and Pera, L. M. (2007). Catalytic properties of mycelium-bound lipases from Aspergillus niger MYA 135. Appl. Microbiol. Biotechnol. 76, 861-866. doi: 10.1007/s00253-007-1067-9

Rooney, D., and Weatherley, L. R. (2001). The effect of reaction conditions upon lipase catalysed hydrolysis of high oleate sunflower oil in a stirred liquid-liquid reactor. Process Biochem. 36, 947-953. doi: 10.1016/S0032-9592(01)00130-3

Saxena, R. K., Davidson, W. S., Sheoran, A., and Giri, B. (2003). Purification and characterization of an alkaline thermostable lipase from Aspergillus carneus. Process Biochem. 39, 239-247. doi: 10.1016/S0032-9592(03)00068-2

Scaldaferri, C. A., and Pasa, V. M. D. (2019). Production of jet fuel and green diesel range biohydrocarbons by hydroprocessing of soybean oil over niobium phosphate catalyst. Fuel 245, 458-466. doi: 10.1016/j.fuel.2019.01.179

Schirmer, A., Rude, M. A., Li, X., Popova, E., and del Cardayre, S. B. (2010). Microbial biosynthesis of alkanes. Science 327, 1385-1389.

Scrutton, N. S. (2017). Enzymes make light work of hydrocarbon production. Science 357, 872-873. doi: 10.1126/science.aao4399
Sharma, A., Chaurasia, S. P., and Dalai, A. K. (2013). Enzymatic hydrolysis of cod liver oil for the fatty acids production. Catal. Today 207, 93-100. doi: 10.1016/j.cattod.2012.05.006

Sharma, A. K., Sharma, V., and Saxena, J. (2016). A review on properties of fungal lipases. Int. J. Curr. Microbiol. Appl. Sci. 5, 123-130. doi: 10.20546/ijcmas.2016. 512.014

Sharma, R., Chisti, Y., and Chand, U. (2001). Production, purification, characterization, and applications of lipases. Biotechnol. Adv. 19, 627-662. doi: 10.1016/S0734-9750(01)00086-6

Shibata, H., Kato, H., and Oda, J. (1998). Calcium ion-dependent reactivation of a Pseudomonas lipase by its specific modulating protein, LipB. J. Biochem. 123, 136-141.

Silva, N. C. A., Miranda, J. S., Bolina, I. C. A., Silva, W. C., Hirata, D. B., de Castro, H. F., et al. (2014). Immobilization of porcine pancreatic lipase on polyhydroxybutyrate particles for the production of ethyl esters from macaw palm oils and pineapple flavor. Biochem. Eng. J. 82, 139-149. doi: 10.1016/j.bej.2013. 11.015

Silva, W. O. B., Santi, L., Berger, M., Pinto, A. F. M., Guimarães, J. A., Schrank, A., et al. (2009). Characterization of a spore surface lipase from the biocontrol agent Metarhizium anisopliae. Process Biochem. 44, 829-834. doi: 10.1016/j.procbio. 2009.03.019

Simons, J. W. F. A., Van Kampen, M. D., Ubarretxena-Belandia, I., Cox, R. C., Alves Dos Santos, C. M., Egmond, M. R., et al. (1999). Identification of a calcium binding site in Staphylococcus hyicus lipase: generation of calcium-independent variants. Biochemistry 38, 2-10. doi: 10.1021/bi9818691

Skjold-Jørgensen, J., Vind, J., Svendsen, A., and Bjerrum, M. J. (2014). Altering the activation mechanism in Thermomyces lanuginosus lipase. Biochemistry 53, 4152-4160. doi: 10.1021/bi500233h

Soares, C. M. F., De Castro, H. F., De Moraes, F. F., and Zanin, G. M. (1999). Characterization and utilization of Candida rugosa lipase immobilized. Appl. Biochem. Biotechnol. 77, 77-79.

Sousa, F. P., Silva, L. N., de Rezende, D. B., de Oliveira, L. C. A., and Pasa, V. M. D. (2018). Simultaneous deoxygenation, cracking and isomerization of palm kernel oil and palm olein over beta zeolite to produce biogasoline, green diesel and biojet-fuel. Fuel 223, 149-156. doi: 10.1016/j.fuel.2018.03.020

Strong, M., Sawaya, M. R., Wang, S., Phillips, M., Cascio, D., and Eisenberg, D. (2006). Toward the structural genomics of complexes: crystal structure of a PE/PPE protein complex from Mycobacterium tuberculosis. Proc. Natl. Acad. Sci. U.S.A. 103, 8060-8065. doi: 10.1073/pnas.0602606103

Sun, Q., Wang, H., Zhang, H., Luo, H., Shi, P., Bai, Y., et al. (2016). Heterologous production of an acidic thermostable lipase with broad-range $\mathrm{pH}$ activity from thermophilic fungus Neosartorya fischeri P1. J. Biosci. Bioeng. 122, 539-544. doi: 10.1016/j.jbiosc.2016.05.003

Svergun, D. I. (1999). Restoring low resolution structure of biological macromolecules from solution scattering using simulated annealing. Biophys. J. 76, 2879-2886. doi: 10.1016/S0006-3495(99)77443-6

Svergun, D. I., Semenyuk, A. V., and Feigin, L. A. (1988). Small-angle-scatteringdata treatment by the regularization method. Acta Crystallogr. Sect. A 44, 244-251. doi: 10.1107/S0108767387011255

Tayyab, M., Rashid, N., and Akhtar, M. (2011). Isolation and identification of lipase producing thermophilic Geobacillus sp. SBS-4S: cloning and characterization of the lipase. J. Biosci. Bioeng. 111, 272-278. doi: 10.1016/j.jbiosc.2010. 11.015

Utsugi, A., Kanda, A., and Hara, S. (2009). Lipase specificity in the transacylation of triacylglycerin. J. Oleo Sci. 58, 123-132. doi: 10.5650/jos.58.123

Volkov, V. V., and Svergun, D. I. (1995). Uniqueness of ab initio shape determination in small-angle scattering. 8898, 717-728.

Walker, R. E. (ed.) (1990). Official Methods and Recommended Practices of the American Oil Chemists' Society, 4th Edn. Champaign, IL: American Oil Chemists' Society.

Wang, M., Chen, M., Fang, Y., and Tan, T. (2018). Highly efficient conversion of plant oil to bio-aviation fuel and valuable chemicals by combination of enzymatic transesterification, olefin cross-metathesis, and hydrotreating. Biotechnol. Biofuels 11:130. doi: 10.1186/s13068-018-1020-4

Wang, W., and Lu, X. (2013). Microbial synthesis of Alka(e)nes. Front. Bioeng. Biotechnol. 1:10. doi: 10.3389/fbioe.2013.00010

Wise, C. E., Grant, J. L., Amaya, J. A., Ratigan, S. C., Hsieh, C. H., Manley, O. M., et al. (2017). Divergent mechanisms of iron-containing enzymes for 
hydrocarbon biosynthesis. J. Biol. Inorg. Chem. 22, 221-235. doi: 10.1007/ s00775-016-1425-0

Xu, H., Ning, L., Yang, W., Fang, B., Wang, C., Wang, Y., et al. (2017). In vitro oxidative decarboxylation of free fatty acids to terminal alkenes by two new P450 peroxygenases. Biotechnol. Biofuels 10:208. doi: 10.1186/s13068-0170894- $\mathrm{x}$

Yan, J., Liu, Y., Wang, C., Han, B., and Li, S. (2015). Assembly of lipase and $\mathrm{P} 450$ fatty acid decarboxylase to constitute a novel biosynthetic pathway for production of 1-alkenes from renewable triacylglycerols and oils. Biotechnol. Biofuels 8:34. doi: 10.1186/s13068-0150219-x

Yu, M., Qin, S., and Tan, T. (2007). Purification and characterization of the extracellular lipase Lip2 from Yarrowia lipolytica. Process Biochem. 42, 384-391. doi: 10.1016/j.procbio.2006.09.019

Zargar, A., Bailey, C. B., Haushalter, R. W., Eiben, C. B., Katz, L., and Keasling, J. D. (2017). Leveraging microbial biosynthetic pathways for the generation of 'dropin' biofuels. Curr. Opin. Biotechnol. 45, 156-163. doi: 10.1016/j.copbio.2017. 03.004
Zhang, F., Rodriguez, S., and Keasling, J. D. (2011). Metabolic engineering of microbial pathways for advanced biofuels production. Curr. Opin. Biotechnol. 22, 775-783. doi: 10.1016/j.copbio.2011.04.024

Zwart, P. H., Grosse-Kunstleve, R. W., and Adams, P. D. (2005). Xtriage and Fest: automatic assessment of X-ray data and substructure structure factor estimation. CCP4 Newsl. 43, 27-35.

Conflict of Interest: The authors declare that the research was conducted in the absence of any commercial or financial relationships that could be construed as a potential conflict of interest.

Copyright (c) 2020 Rade, da Silva, Vieira, Milan, de Souza, de Melo, Klein, Bonomi, de Castro, Murakami and Zanphorlin. This is an open-access article distributed under the terms of the Creative Commons Attribution License (CC BY). The use, distribution or reproduction in other forums is permitted, provided the original author(s) and the copyright owner(s) are credited and that the original publication in this journal is cited, in accordance with accepted academic practice. No use, distribution or reproduction is permitted which does not comply with these terms. 